\title{
Mechanisms of Long Non-Coding RNAs in Cancers and Their Dynamic Regulations
}

\author{
Xiao-Zhen Zhang ${ }^{\dagger}$, Hao Liu ${ }^{\dagger}$ and Su-Ren Chen ${ }^{*} \mathbb{C}$ \\ Education Key Laboratory of Cell Proliferation \& Regulation Biology, College of Life Sciences, Beijing Normal \\ University, Beijing 100875, China; zhangxz91@yeah.net (X.-Z.Z.); liuhaobnu89@yeah.net (H.L.) \\ * Correspondence: chensr@bnu.edu.cn; Tel.:+86-010-58808117; Fax: +86-010-58804121 \\ + These authors contributed equally to this work.
}

Received: 20 April 2020; Accepted: 12 May 2020; Published: 15 May 2020

check for updates

\begin{abstract}
Long non-coding RNA (lncRNA), which is a kind of noncoding RNA, is generally characterized as being more than 200 nucleotide transcripts in length. LncRNAs exhibit many biological activities, including, but not limited to, cancer development. In this review, a search of the PubMed database was performed to identify relevant studies published in English. The term "IncRNA or long non-coding RNA" was combined with a range of search terms related to the core focus of the review: mechanism, structure, regulation, and cancer. The eligibility of the retrieved studies was mainly based on the abstract. The decision as to whether or not the study was included in this review was made after a careful assessment of its content. The reference lists were also checked to identify any other study that could be relevant to this review. We first summarized the molecular mechanisms of lncRNAs in tumorigenesis, including competing endogenous RNA (ceRNA) mechanisms, epigenetic regulation, decoy and scaffold mechanisms, mRNA and protein stability regulation, transcriptional and translational regulation, miRNA processing regulation, and the architectural role of lncRNAs, which will help a broad audience better understand how lncRNAs work in cancer. Second, we introduced recent studies to elucidate the structure of lncRNAs, as there is a link between IncRNA structure and function and visualizing the architectural domains of lncRNAs is vital to understanding their function. Third, we explored emerging evidence for regulators of lncRNA expression, lncRNA turnover, and lncRNA modifications (including 5-methylcytidine, N6-methyladenosine, and adenosine to inosine editing), highlighting the dynamics of lncRNAs. Finally, we used autophagy in cancer as an example to interpret the diverse mechanisms of lncRNAs and introduced clinical trials of lncRNA-based cancer therapies.
\end{abstract}

Keywords: IncRNA; cancer; mechanism; turnover; secondary structure; modification; autophagy; review

\section{Introduction}

The central dogma of the molecular biology of DNA-RNA-protein proposes that genetic information is stored in protein-coding genes [1]. From the traditional point of view, proteins are the main performers of cellular function, while RNA is considered to be an intermediary between genes and proteins. Surprisingly, the international Human Genome Project (HGP) has revealed that more than $90 \%$ of the genome is comprised of non-coding genes [2,3].

Recent transcriptome sequencing has discovered, across various species, thousands of long non-coding RNAs (lncRNAs), which are most commonly defined as non-protein-coding RNA molecules longer than 200 nucleotides. LncRNAs can be categorized as intergenic, intronic, sense, or antisense, according to their location and transcription pattern. Intergenic lncRNAs refers to lncRNAs that are transcribed from regions between protein-coding genes, whereas those transcribed from the introns of genes are known as intronic lncRNAs. Transcribed lncRNAs from the sense strand of protein-coding 
genes are termed sense lncRNAs, and antisense lncRNAs, on the contrary, are transcribed from the antisense strand $[4,5]$.

Coding and non-coding genes are generally classified by their protein-coding potential or whether the transcripts need to be translated to protein to perform their functions. Both a large non-coding transcriptome and extensive alternative splicing contribute to the complex genome and generation of a great diversity of lncRNAs [6,7]. Interestingly, recent studies have identified lncRNAs that harbor small open reading frames to encode short functional peptides [8-10] (Figure 1A). Protein and IncRNA can be encoded by the same gene. For example, exposure to ultraviolet (UV) light leads to a slowdown of transcript elongation; upon UV irradiation, the activating signal co-integrator complex 3 (ASCC3) gene expresses a shorter RNA isoform (lncRNA ASCC3) that mediates transcription recovery after UV-induced DNA damage [11] (Figure 1B). Furthermore, Grelet et al. characterized the binding of heterogeneous nuclear ribonucleoprotein E1 (hnRNPE1) to the DNA element in exon 12 of the serine/threonine-protein phosphatase 1 regulatory subunit 10 (PNUTS) gene that regulates its alternative splicing to generate lncRNA PNUTS [12] (Figure 1C).

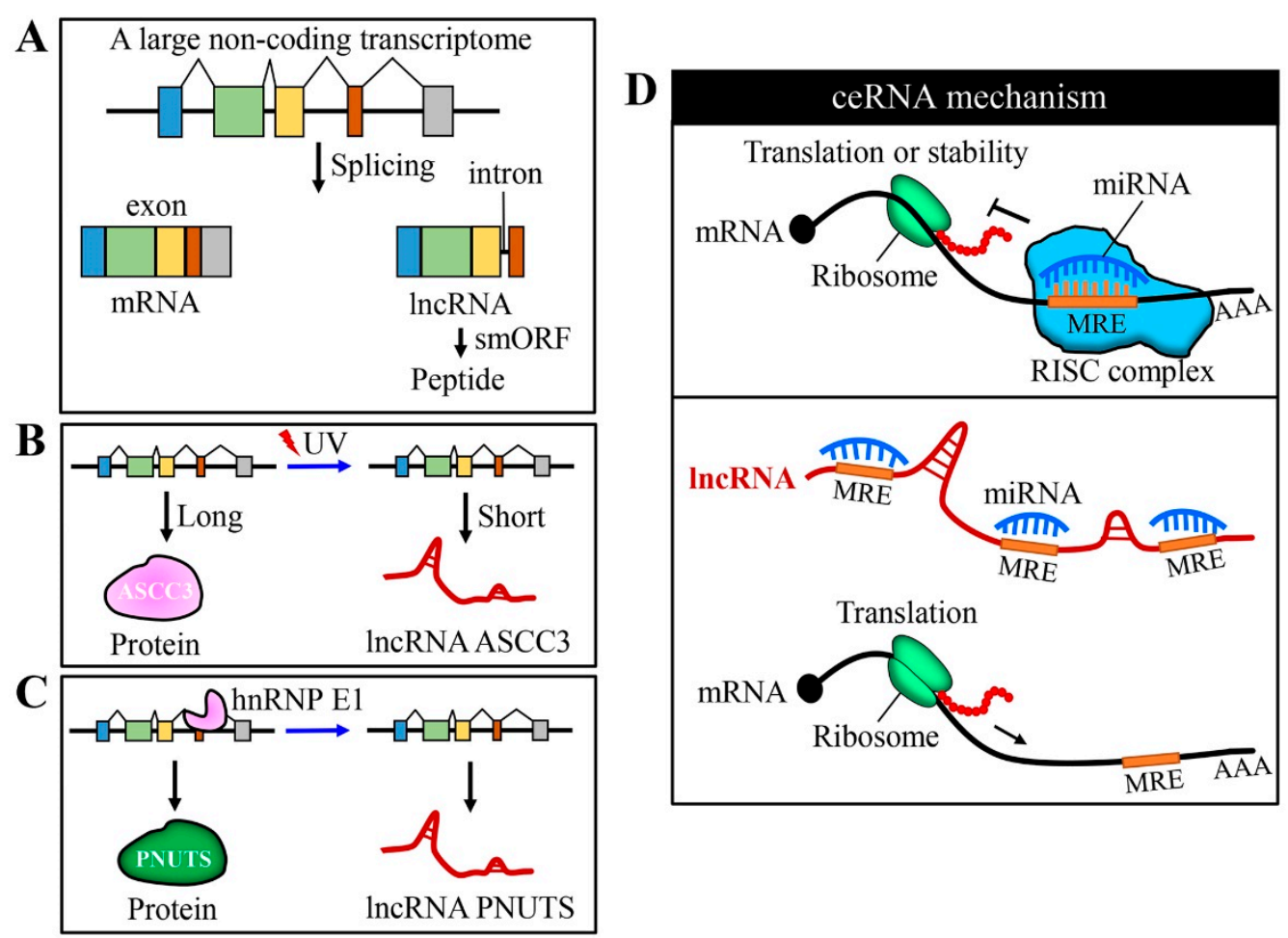

Figure 1. Generation of long non-coding RNAs (lncRNAs) and their function as competing endogenous RNA (ceRNA). (A) Alternative splicing gives rise to the complex mammalian genome; lncRNA variants may arise from the skipping of the first or last exon, resulting in the loss of start or stop codons. A part of lncRNAs harbors small open reading frames (smORF) and can encode short peptides with a function. (B) Protein and lncRNA can sometimes be encoded by the same gene. Exposure to UV light leads to a slowdown of transcript elongation and the ASCC3 gene expresses a shorter RNA isoform (lncRNA ASCC3), instead of protein. (C) The binding of heterogeneous nuclear ribonucleoprotein E1 (hnRNPE1) to a nucleic element within exon 12 of the serine/threonine-protein phosphatase 1 regulatory subunit 10 (PNUTS) gene that regulates its alternative splicing to generate the lncRNA PNUTS. (D) In general, miRNAs bind to the $3^{\prime}$ untranslated (UTR) region of target mRNAs and regulate their expression at a post-transcription level (inhibiting translation and/or decreasing the stability of mRNA). LncRNAs can act as sponges for miRNA through their binding sites and inhibit the function of miRNA on its target gene(s). 
Until now, many cancer risk-associated loci have been explored in large-scale genome-wide association studies (GWASs). Notably, a high proportion of GWAS-identified cancer susceptibility gene variants are located in the non-coding regions of the genome [13-18]. LncRNAs, such as RP11-403A21.1 at 18q11.2, are highly associated with the human ovarian cancer risk [19]. Forty-five candidate lncRNAs have been identified in GWASs as being associated with the risk for prostate cancer [20]. Cyclin D1 (CCND1)-upstream intergenic DNA repair 1 and 2 (lncRNA CUPID1/2) mediates the breast cancer risk at 11q13 by modulating the cellular response to DNA damage [21]. The role of lncRNAs in cancer biology is continually expanding; importantly, some cancer-associated lncRNAs are clinically relevant. For example, a recent study identified 1145 temporally expressed S-phase-enriched lncRNAs, and silencing of some of them in cancer models affects crucial cancer cell hallmarks [22]. Moreover, a small subset of lncRNAs has been identified as being strongly correlated with the treatment response and survival in acute myeloid leukemia [23]. Bromodomain and extra-terminal motif (BET) inhibitors have been demonstrated to be a promising new therapy in several cancer types, and the IncRNA pharmacogenomics landscape suggests that epigenetically-induced lncRNA1 (EPIC1) stimulates BET inhibitor resistance via the activation of MYC proto-oncogene, bHLH transcription factor (MYC) transcription [24]. Collectively, lncRNAs have emerged as novel regulators of human cancer development; however, the mechanism by which lncRNA exerts its molecular function remains largely uncharacterized.

In this up-to-date review, we mainly summarize the diverse mechanisms of lncRNA actions in cancer pathology and discuss the turnover, secondary structure, and modifications of lncRNA. Finally, we briefly introduce the lncRNAs involved in autophagy in cancer and clinical trials of lncRNA-based cancer therapies. We hope that the current review, summarizing the regulatory mechanisms of lncRNAs and their dynamic regulations in cancer biology, will be of a certain significance for researchers, doctors, and graduate students in the field of IncRNA and cancer, and allow the general public to obtain useful and timely information. We need to point out that many interesting topics relating to lncRNAs are not included here due to the focus of this review, such as lncRNAs and epithelial-mesenchymal transition (EMT), IncRNAs and cancer cell stemness, lncRNAs and chemo/radioresistance, clinical trials involving lncRNAs, IncRNA delivery strategies, lncRNAs as biomarkers, exosomal lncRNAs and cell-cell communication, and lncRNA database collection.

\section{Regulatory Mechanisms of LncRNAs in Cancer Progression}

\subsection{Competing Endogenous RNA (ceRNA) Mechanism}

MiRNAs bind to sequences with partial complementarity on target RNA transcripts using miRNA recognition elements (MREs). LncRNAs can act as sponges for miRNA through their MREs and modulate the activity of miRNA on its target mRNAs. LncRNAs compete with mRNA targets for binding to miRNAs, thus relieving the inhibitory action of miRNAs on mRNA targets $[25,26]$ (Figure 1D). Recent studies have characterized dysregulated lncRNA-miRNA-mRNA networks based on ceRNA theory. We briefly summarized recent studies adopting the ceRNA mechanism to explain the action of lncRNA (Table 1).

Table 1. Examples of the competing endogenous RNA (ceRNA) mechanism.

\begin{tabular}{ccccc}
\hline LncRNA & miRNA & mRNA & Cancer Type & Ref \\
\hline PTENP1 & PTEN-targeting miRNAs & PTEN & Various tumor cells & {$[27]$} \\
LINC00673 & miR-150-5p & ZEB1 & Lung cancer & {$[28]$} \\
ODRUL & miR-3182 & $M M P 2$ & Osteosarcoma & {$[29]$} \\
LINC01234 & miR-204-5p & CBFB & Gastric cancer & {$[30,31]$} \\
NEAT1 & miR-34a & SIRT1 & Colorectal cancer & {$[32]$} \\
WDFY3-AS2 & miR-18a & RORA & Ovarian cancer & {$[33]$} \\
\hline
\end{tabular}


PTEN pseudogene (lncRNA PTENP1) is derived from its homologous protein-coding gene phosphatase and tensin homolog (PTEN) due to a missense mutation of the methionine (Met) codon preventing translation. LncRNA PTENP1 acts as a decoy for PTEN-targeting miRNAs to regulate PTEN expression [27]. LINC00673 sponges miR-150-5p to modulate the expression of zinc finger E-box binding homeobox 1 (ZEB1), a key epithelial-mesenchymal transition regulator, in non-small cell lung cancer [28]. Osteosarcoma doxorubicin-resistance related up-regulated lncRNA (ODRUL) combines with miR-3182 to elevate matrix metalloproteinase 2 (MMP2) expression in osteosarcoma [29]. In gastric cancer, LINC01234 functions as a ceRNA to regulate core-binding factor $\beta$ (CBFB) expression by sponging miR-204-5p [30,31]. Colorectal cancer progression is promoted by nuclear paraspeckle assembly transcript 1 (lncRNA NEAT1), which competitively binds miR-34a with histone deacetylase sirtuin 1 (SIRT1) [32]. In ovarian cancer, the WD repeat and FYVE domain containing 3-antisense 2 (lncRNA WDFY3-AS2) sponges miR-18a to upregulate nuclear receptor RAR-related orphan receptor A (RORA) [33].

Importantly, there are several issues that should be noted: (i) whether IncRNAs effectively function as ceRNAs at physiologically relevant copy numbers is debatable because most of the studies describing miRNA sponges rely on overexpression; (ii) whether ceRNA theory is truly the principle mechanism of lncRNA function is sometimes questionable, and the reason why a large amount of literature claims ceRNAs as the mechanism of lncRNA action; (iii) whether the loss of lncRNAs is precisely responsible for the phenotype needs to be confirmed because some lncRNAs harbor small open reading frames and encode functional short peptides [10,34-37]; (iv) the ceRNA effect is affected by the abundance of miRNAs and lncRNAs, the number and affinity of binding sites, and the degree of miRNA/mRNA complementarity $[38,39]$. Further studies are therefore needed to determine the molecular mechanisms by which miRNA will be sponged or activated to degrade its target transcripts.

\subsection{Epigenetic Regulation by $\operatorname{lnc} R N A s$}

In addition to the ceRNA mechanism, lncRNAs directly participate in cancer epigenetic regulation via interacting with key histone-modification enzymes [40]. Current studies have identified that IncRNAs can modulate downstream gene expression through interacting with chromatin remodeling complexes, including polycomb repressive complexes (PRCs), mixed-lineage leukemia 1 (MLL1), and SWI/SNF complexes.

PRCs are composed of PRC1 and PRC2 and modify histones to mediate gene silencing [41,42]. The PRC1 complex mainly contains Bmi1/Mel18, mPh1/2, Pc/Chromobox (CBX), and the ubiquitin E3 ligase RING1A/B, whereas the PRC2 complex is formed of EED, Suz12, and methyltransferase EZH2. Notably, a large proportion of lncRNAs ( $20 \%)$ expressed in various cell types are found in association with the PRC2 complex [43]. More than 9000 lncRNAs associated with PRC2 in embryonic stem cells have been identified by RNA binding protein immunoprecipitation (RIP)-seq analysis [44]. Here, we briefly summarize recent studies on the epigenetic regulation conducted by lncRNAs in cancer progression (Table 2).

Antisense non-coding RNA in the INK4 locus (ANRIL) binds to CBX7 within the PRC1 complex to form heterochromatin surrounding the INK4b-ARF-INK4a locus, leading to its repression in prostate cancer [45]. HOX transcript antisense intergenic RNA (HOTAIR) is well-known lncRNA located in the HOXC gene cluster and regulates HOXD cluster genes on a different chromosome via the recruitment of the PRC2 complex with its $5^{\prime}$-end to mediate transcriptional silencing [46] (Figure 2A). LncRNA plasmacytoma variant translocation 1 (PVT1) promotes gastric cancer cell proliferation by targeting the occupancy of EZH2 within the PRC2 complex to epigenetically regulate $p 15$ and $p 16$ [47]. A conserved sequence element in the long intergenic non-protein-coding RNA p53-induced transcript (LINC-PINT) has been shown to mediate LINC-PINT-PRC2 interaction, which is necessary for the repression of pro-invasive genes [48]. Furthermore, IncRNAs can modulate chromatin signatures to establish alternative splicing; fibroblast growth factor receptor 2 (FGFR2)-antisense (LncRNA FGFR2-AS) 
generates a splicing-specific chormatin signature to favor exon IIIb inclusion in epithelial cells through recruiting PRC2 and histone demethylase KDM2a to the FGFR2 locus [49,50] (Figure 2B).

Table 2. Epigenetic regulation by lncRNAs.

\begin{tabular}{ccccc}
\hline LncRNA & $\begin{array}{c}\text { Chromatin Remodeling } \\
\text { Complexes }\end{array}$ & Locus & Cancer Type & Ref \\
\hline ANRIL & PRC1 (CBX7) & INK4b-ARF-INK4a & Prostate cancer & {$[45]$} \\
HOTAIR & PRC2 & HOXD cluster & Breast cancer & {$[46]$} \\
PTV1 & PRC2 (EZH2) & p15, p16 & Gastric cancer & {$[47]$} \\
LINK-PINT & PRC2 & Pro-invasive genes & Lung/colon cancer & {$[48]$} \\
FGFR2-AS & PRC2/KDM2a & FGFR2 & Epithelial cell & {$[49,50]$} \\
HOXD-AS1 & WDR5 & Target genes & Prostate cancer & {$[51]$} \\
GCAWKR & WDR5/KAT2A & Target genes & Gastric cancer & {$[52]$} \\
GAS8-AS1 & MLL1/WDR5 & GAS8 & Liver cancer & {$[53]$} \\
LncFZD6 & SWI/SNF (BRG1) & FZD6 & Liver cancer & {$[54]$} \\
SATB2-AS1 & p300 & SATB2 & Colorectal cancer & {$[55]$} \\
HAND2-AS1 & INO80 & BMPR1A & Liver cancer & {$[56]$} \\
LnCHOXA10 & NURF & HOXA10 & Liver cancer & {$[57]$} \\
PYCARD-AS1 & DNMT1/G9a & PYCARD & Breast cancer & {$[58]$} \\
\hline
\end{tabular}

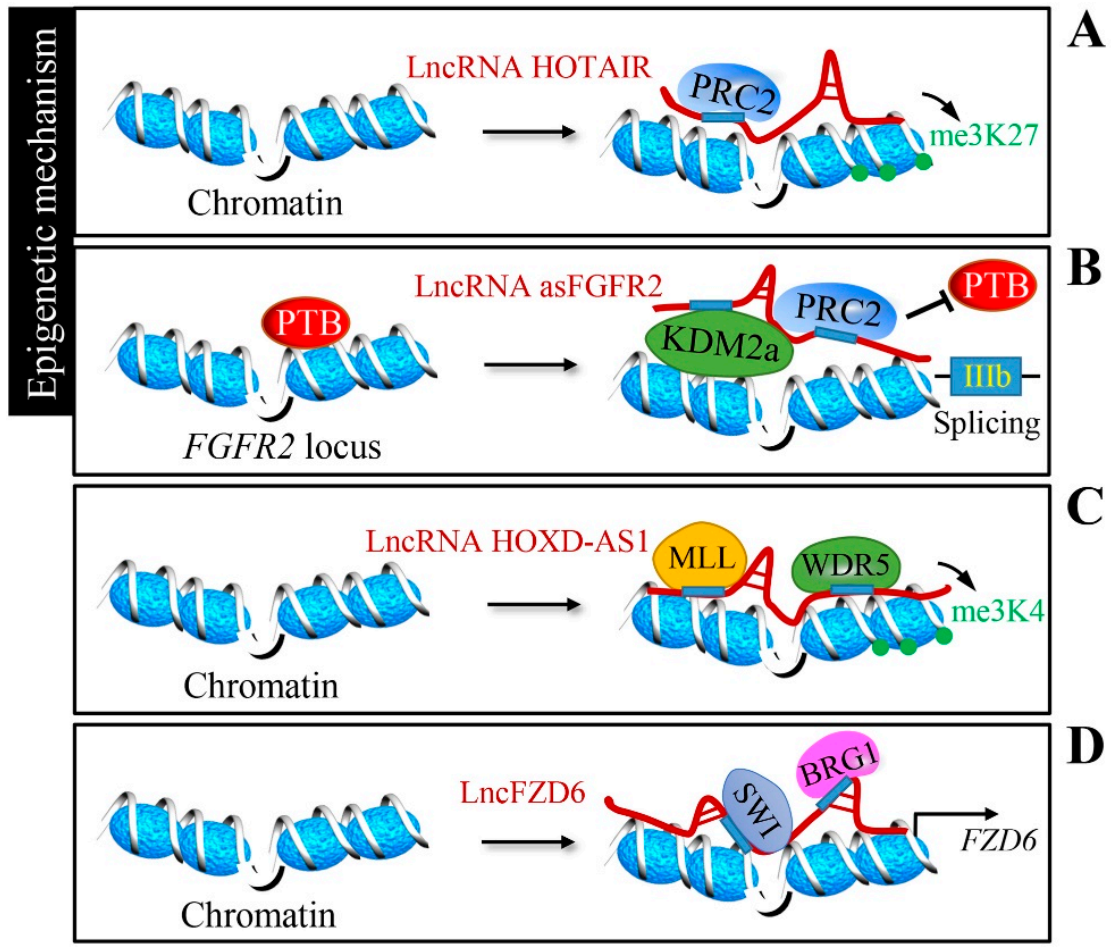

Figure 2. Epigenetic regulation by lncRNAs. (A) LncRNA HOX transcript antisense intergenic RNA (HOTAIR) regulates HOXD cluster genes via the recruitment of the polycomb repressive complex 2 (PRC2) silencing complex to execute gene silencing by histone $\mathrm{H} 3$ lysine 27 tri-methylation (H3K27me3). (B) LncRNA FGFR2-AS recruits the PRC2 complex and histone demethylase KDM2a to the FGFR2 locus, generating a splicing-specific chromatin signature. (C) LncRNA HOXD antisense growth-associated long non-coding RNA (HOXD-AS1) recruits the WD repeat domain 5 (WDR5)-mixed-lineage leukemia (MLL) complex and mediates histone $\mathrm{H} 3$ lysine 4 tri-methylation (H3K4me3) to directly regulate the expression of target genes. (D) Divergent lncRNA of FZD6 (LncFZD6) recruits the BRG1-embedded SWI/SNF complex to the FZD6 promoter and drives FZD6 transcription. 
MLL1 is a histone H3Lys4 (H3K4) methyltransferase and forms a complex with WD repeat domain 5 (WDR5) and other components. WDR5 has been proven to associate with lncRNAs to preserve the activation of chromatin [59,60]. HOXD antisense growth-associated long non-coding RNA (HOXD-AS1) promotes the proliferation and chemoresistance of prostate cancer by recruiting WDR5 to regulate target genes via H3K4 tri-methylation [51] (Figure 2C). Gastric cancer-associated WDR5 and KAT2A binding lncRNA (GCAWKR) modulates the affinity for WDR5/KAT2A complexes in the promoter region of target genes [52]. In hepatocarcinogenesis, enhanced growth arrest specific 8 (GAS8) transcription is achieved by recruitment of the MLL1/WDR5 complex via lncRNA GAS8-AS1 [53]. The SWI/SNF complex is another well-studied chromatin remodeling complex. Divergent lncRNA of FZD6 (lncFZD6) recruits the BRG1 (Brahma-related gene 1; SMARCA4)-embedded SWI/SNF complex to the FZD6 promoter, driving the FZD6 transcription in liver cancer [54] (Figure 2D).

Moreover, lncRNAs serve as a scaffold to recruit other chromatin-remodeling complexes or histone acetyl/methyl-transferases to target chromatin, including E1A binding protein p300 (p300), the INO80 complex ATPase subunit (INO80), DNA methyltransferase 1 (DNMT1), euchromatic histone lysine methyltransferase 2 (G9a), and the Drosophila nucleosome-remodeling factor (NURF). An antisense transcript of SATB homeobox 2 (SATB2) (lncRNA SATB2-AS1) could serve as a scaffold to recruit histone acetyltransferase p300 to downregulate SATB2 expression and promote colorectal carcinoma progression [55]. Liver cancer stem cell self-renewal requires the recruitment of chromatin-remodeling complex INO80 to the BMPR1A promoter by the action of an antisense transcript of HAND2 (lncRNA HAND2-AS1) [56]. Similarly, liver tumor-initiating cell maintenance requires HOXA10 transcription by the lncHOXA10-mediated recruitment of chromatin remodeling complex NURF [57]. The antisense transcript of PYD and CARD domain containing (PYCARD) (lncRNA PYCARD-AS1) could recruit DNMT1 and histone methyltransferase G9a to the PYCARD promoter to further regulate apoptosis [58].

\subsection{Decoy Mechanism}

LncRNAs can function as a decoy of transcription factors to sequester from their DNA-binding sequences, in order to regulate target gene expression. For example, P50-associated COX-2 extragenic RNA (IncRNA PACER) separates the repressive nuclear factor kappa B subunit 1 (NF-kB) subunit p50 from the cytochrome c oxidase subunit II (COX-2) promoter to activate COX-2 gene expression [61] (Figure 3A). Colorectal cancer growth and metastasis could be promoted by the release of oncogene PTBP2 from the SFPQ/PTBP2 complex, which is achieved by the affinity between human metastasis-associated lung adenocarcinoma transcript 1 (lncRNA MALAT1) and SFPQ [62] (Figure 3B). Ovarian adenocarcinoma-amplified lncRNA (OVAAL) binds to polypyrimidine tract-binding protein 1 (PTBP1) and reduces the recruitment of PTBP1 to the internal ribosome entry site of $p 27$ mRNA, thus imparting an inhibitory effect on $p 27$ mRNA translation in cancer cells [63] (Figure 3C). LncRNAs can also repel endogenous histone methyltransferase; for example, the regulator of reprogramming (lncRNA ROR) competes with histone G9A methyltransferase at the tescalcin (TESC) promoter, inducing aberrant TESC expression to trigger gastric and colon tumorigenesis [64] (Figure 3D). 


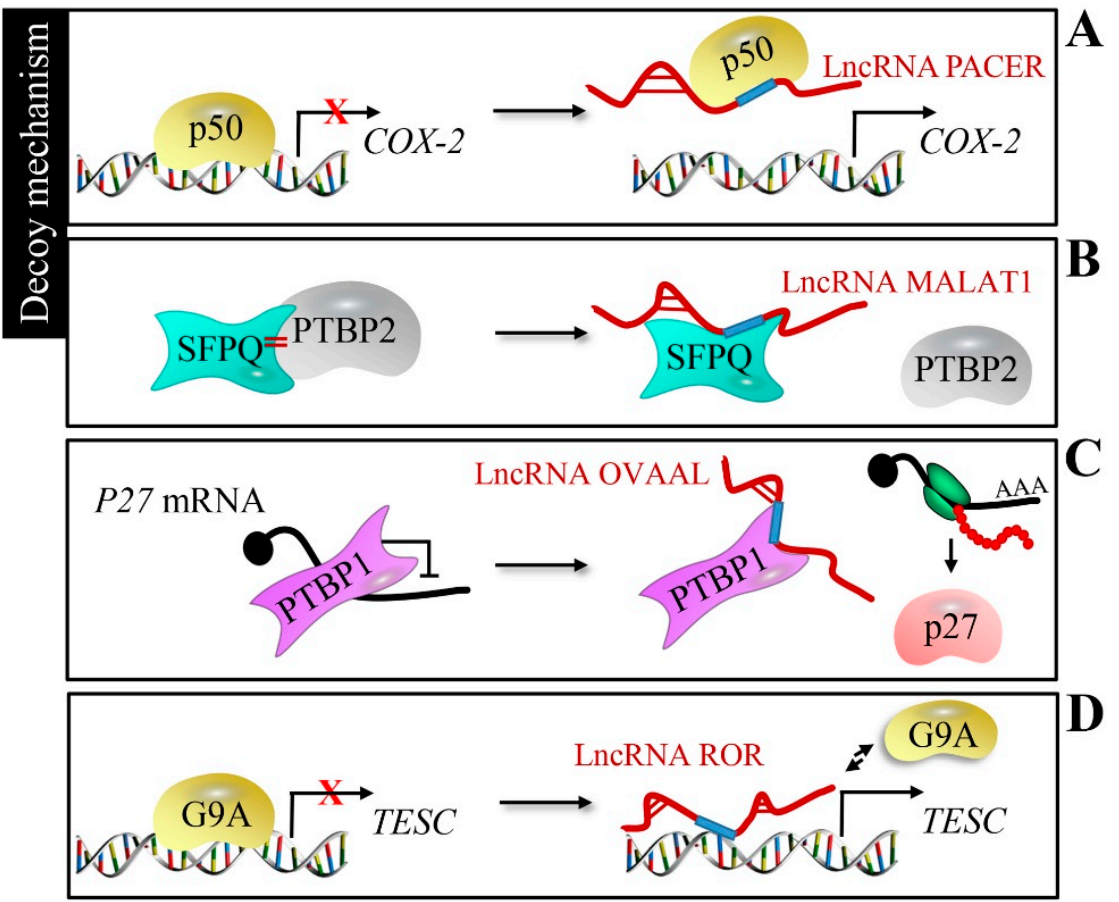

Figure 3. Decoy mechanism of lncRNAs. (A) LncRNA PACER interacts with the p50 to separate it from the cytochrome c oxidase subunit II (COX-2) promoter, activating COX-2 gene expression. (B) LncRNA MALAT1 binds to SFPQ and releases oncogene PTBP2 from the SFPQ/PTBP2 complex. (C) LncRNA ovarian adenocarcinoma-amplified lncRNA (OVAAL) with $p 27$ mRNA competitively binds to PTBP1 to release the inhibition of $p 27$ expression. (D) LncRNA ROR competes with histone G9A methyltransferase at the tescalcin (TESC) promoter, and free G9A fails to methylate the TESC promoter.

\subsection{LncRNA Control of $m R N A$ and Protein Stability}

Although proteins are the main executors of cellular function, nearly half of the changes in expression occur at the RNA level, specifically through the control of RNA stability [65]. Accumulating evidence suggests that lncRNAs are novel regulators of the mRNA stability of oncogenes or cancer suppressor genes (Table 3). Kumar et al. indicated that urothelial carcinoma associated 1 (lncRNA UCA1) stabilizes CDKN2A-p16 mRNA by sequestering heterogeneous nuclear ribonucleoprotein A1 (hnRNPA1) [66] (Figure 4A). ELAV-like RNA binding protein 1 (HuR), an RNA-binding posttranscriptional regulator, affects mRNA stability through binding to the RNA motif and is implicated in cancer formation, progression, and metastasis. Programmed cell death 4 (PDCD4)-antisense RNA1 (lncRNA PDCD4-AS1) stabilizes PDCD4 mRNA by forming an RNA duplex and increases the interaction between PDCD4 mRNA and HuR in breast cancer [67] (Figure 4B).

Table 3. LncRNA control of mRNA and protein stability.

\begin{tabular}{ccccc}
\hline LncRNA & LncRNA Interactor & mRNA/Protein Stability & Cancer Type & Ref \\
\hline UCA1 & hnRNPA1 & CDKN2A- $p 16$ & - & {$[66]$} \\
PDCD4-AS1 & HuR & PDCD4 & Breast cancer & {$[67]$} \\
PVT1 & - & MYC & 8q24-amplified cancer cells & {$[68]$} \\
LINK-A & BRK, LRRK2 & HIF1 $\alpha$ & Breast cancer & {$[69]$} \\
ANCR & - & EZH2 & Breast cancer & {$[70]$} \\
GAS5 & - & YAP & Colorectal cancer & {$[71]$} \\
\hline
\end{tabular}




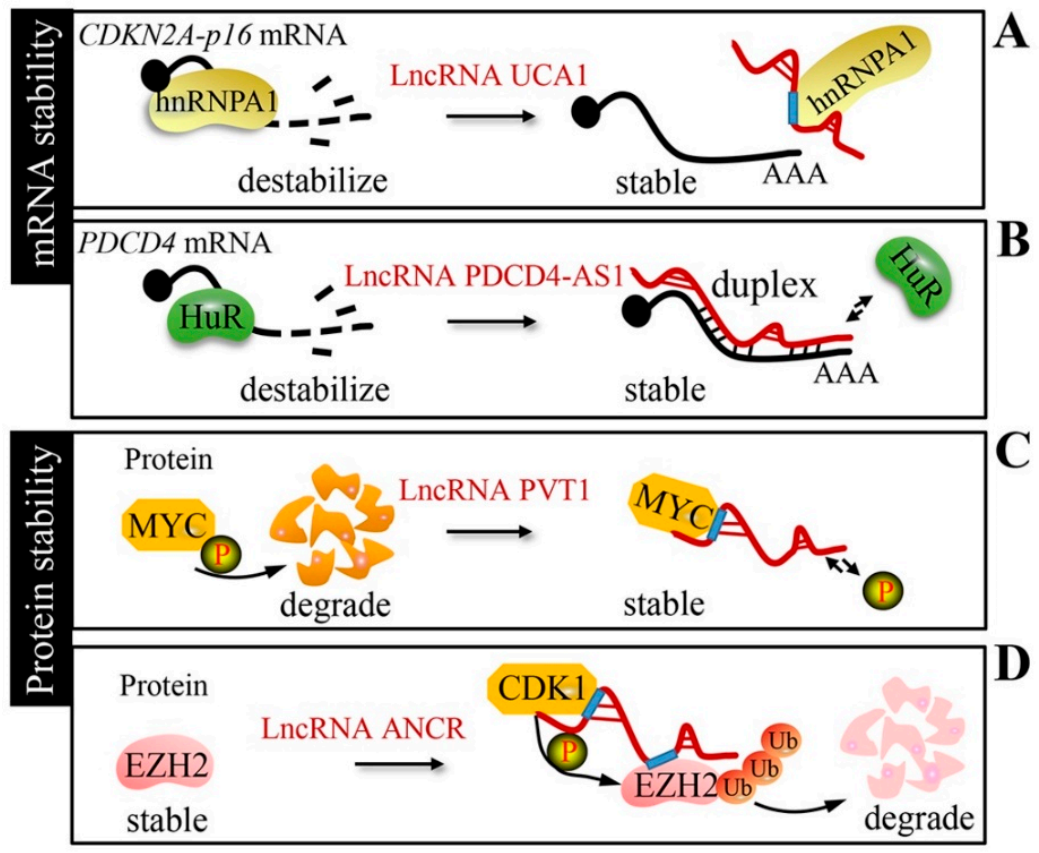

Figure 4. Stability mechanism. (A) LncRNA UCA1 stabilizes CDKN2A-p16 mRNA by sequestering heterogeneous nuclear ribonucleoprotein A1 (hnRNPA1). (B) LncRNA PDCD4-AS1 forms an RNA duplex with PDCD4 mRNA to expel ELAV-like RNA binding protein 1 (HuR). (C) LncRNA plasmacytoma variant translocation 1 (PVT1) protects the MYC protein from phosphorylation-mediated degradation. (D) LncRNA ANCR interacts with EZH2 and promotes the CDK1-mediated phosphorylation and degradation of EZH2.

In addition to being an mRNA stability regulator, IncRNAs have been reported to protect protein stability (Table 3). LncRNA PVT1 has no effect on MYC mRNA stability, but protects the MYC protein from phosphorylation-mediated degradation in 8q24-amplified human cancer cells [68] (Figure 4C). In triple-negative breast cancer, long intergenic non-coding RNA for kinase activation (LINK-A) mediates hypoxia inducible factor 1 subunit alpha (HIF1 $\alpha)$ phosphorylation and stabilization by protein tyrosine kinase 6 (BRK) and leucine rich repeat kinase 2 (LRRK2) interaction [69]. On the other hand, lncRNAs can interact with proteins and limit protein stability via degradation in cancers. Anti-differentiation non-coding RNA (lncRNA ANCR) suppresses breast cancer progression by promoting the cyclin dependent kinase 1 (CDK1)-mediated phosphorylation and degradation of EZH2 [70] (Figure 4D). Growth arrest-specific transcript 5 (lncRNA GAS5) promotes Yes1-associated transcriptional regulator (YAP) degradation via the ubiquitin-proteasome pathway by interacting with the WW domain of the YAP protein in colorectal cancer [71].

\subsection{Transcriptional and Translational Regulation by LncRNAs}

In addition to controlling mRNA stability, the interaction between lncRNA and mRNA can disturb mRNA translation. Antisense to the pro-apoptotic gene PYCARD (lncRNA PYCARD-AS1) inhibits the ribosome assembly for PYD and CARD domain-containing (PYCARD) translation by interacting with PYCARD mRNA [58] (Figure 5A). A low expression in bladder cancer stem cells (lncRNA LBCS) forms a complex with the RNA-binding protein hnRNPK and androgen receptor (AR) mRNA to suppress $A R$ translation in prostate cancer [72] (Figure 5B). In addition to the regulation of translation, interestingly, lncRNAs can affect transcription by modulating the local chromatin structure. An antisense lncRNA named BGas interacts with high mobility group proteins HMGA1 and HMGB1, as well as the partner of Y14 and mago (WIBG), to regulate CFTR gene transcription through the modulation of its DNA architecture and local chromatin [73]. 


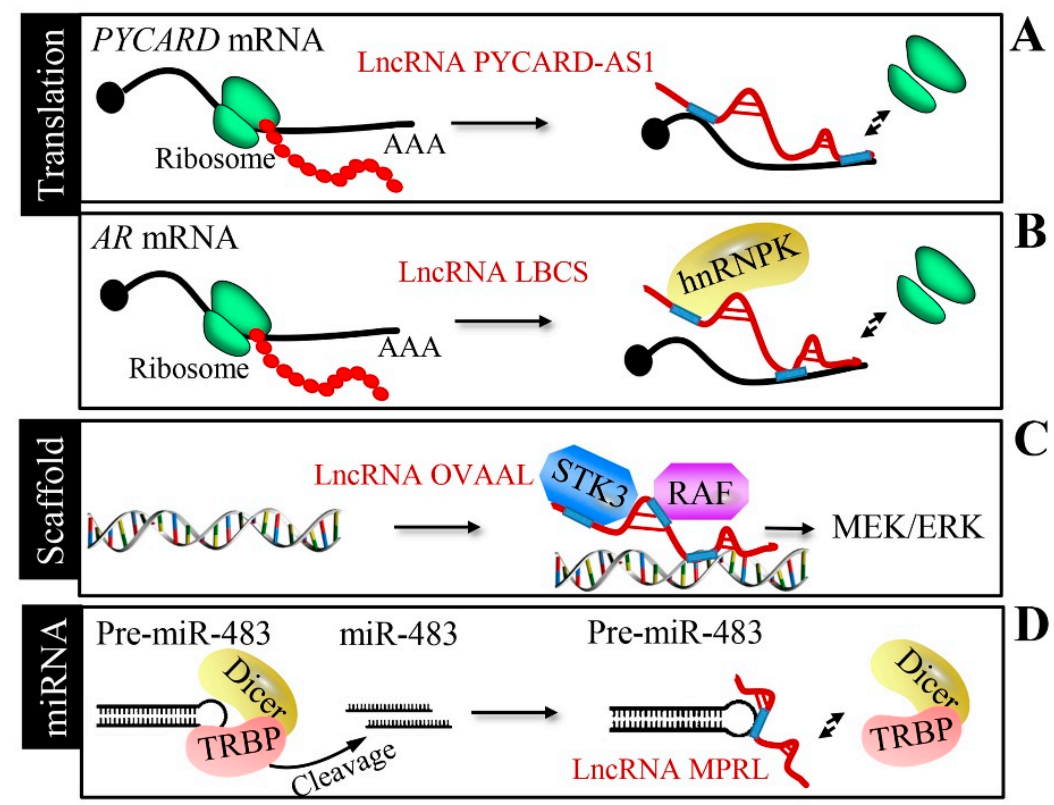

Figure 5. Translation regulation, transcription factor scaffold, and miRNA processing by lncRNAs. (A) LncRNA PYCARD-AS1 interacts with PYCARD mRNA via the $5^{\prime}$ overlapping region, inhibiting ribosome assembly for PYCARD translation. (B) LncRNA LBCS suppresses the $A R$ translation efficiency by forming a complex with hnRNPK and $A R$ mRNA. (C) Like a scaffold, lncRNA OVAAL enhances the binding of serine/threonine-protein kinase 3 (STK3) and RAF to trigger MEK/ERK activation. (D) LncRNA miRNA processing-related lncRNA (MPRL) inhibits miR-483-5p generation by binding with pre-miR-483 to block pre-miR-483 cleavage by the human immunodeficiency virus transactivating response RNA-binding protein (TRBP)-Dicer complex.

\subsection{Scaffold of Transcription Factors by LncRNAs}

LncRNA OVAAL physically interacts with serine/threonine-protein kinase 3 (STK3), enhancing the binding between STK3 and the Raf-1 proto-oncogene, serine/threonine kinase (RAF1), in multiple cancers [63] (Figure 5C). The RBM5 anti-sense transcript (lncRNA RBM5-AS1) sustains the function of colon cancer-initiating cells through the organization of a transcriptional complex containing $\beta$-catenin and transcription factor 4 (TCF4) [74]. LINC00844 facilitates AR binding to the chromatin to determine prostate cancer progression [75].

\section{7. miRNA Processing Mechanism}

Some lncRNAs, such as mitochondrial dynamic-related lncRNA (MDRL) and miRNA processing-related lncRNA (MPRL), can exert their function by regulating miRNA processing. Nucleus miR-361 disturbs the drosha ribonuclease III (Drosha)-mediated cleavage of pri-miR-484 into pre-miR-484; interestingly, IncRNA MDRL regulates miR-484 processing by antagonizing miR-361 [76]. LncRNA MPRL inhibits the Dicer (dicer 1, ribonuclease III)-mediated processing of miR-483 through affinity interaction with pre-miR-482 [77] (Figure 5D).

\subsection{Architectural Role of LncRNAs}

Recent studies have identified nuclear-enriched abundant transcript 1 (lncRNA NEAT1)-containing structures that are referred to as "paraspeckles". Paraspeckles are localized in the interchromatin space of cellular nuclei and perform critical functions, including, but not limited to, gene expression network regulation [78-80]. Here, we introduce the most recent advances in the understanding of paraspeckle functions. Hypoxia stimulates tumor development, partially through the HIF- $2 \alpha$-mediated transcriptional activation of lncRNA NEAT1 and the formation of nuclear paraspeckles [81]. Furthermore, lncRNA NEAT1 is a promising target for increasing the sensitivity of cancer cells to 
chemotherapy [82]. LncRNA NEAT1-containing paraspeckles also stimulate interleukin 6 (IL-6)-mediated hepatocellular carcinoma development by the nuclear entrapping of IL-6/signal transducer and activator of transcription 3 (STAT3) inhibitors [83]. A recent study identified the relationship between mitochondrial stress, IncRNA NEAT1 paraspeckles, and mitochondrial homeostasis; lncRNA NEAT1 depletion alters the sequestration of mitochondrial mRNAs in paraspeckles to influence mitochondrial homeostasis [84]. Although lncRNA NEAT1 plays important roles in paraspeckles, the function and regulatory mechanisms of paraspeckles, as well as the involvement of other lncRNAs in biological paraspeckle activities, are largely unknown.

\subsection{Other Mechanisms of LncRNA Function}

LncRNAs can work through other uncommon mechanisms, including, but not limited to, promoter completion, chromatin enrichment, alternative splicing, and 3' UTR binding. Cho et al. provided interesting data indicating that the IncRNA PVT1 promoter inhibits oncogene MYC expression at the same chromosome via promoter competition [85]. Hemin-induced cheRNA downstream of fetal hemoglobin (lncRNA HIDALGO), a chromatin-enriched lncRNA, tightly associates with chromatin and forms a bridge between the enhancer of HIDALGO transcription start sites and the hemoglobin subunit gamma 1 (HBG1) promoter [86]. Gordon et al. have suggested that lncRNA MALAT1 promotes ovarian cancer progression by regulating the splicing factor RNA binding fox-1 homolog 2 (RBFOX2)-mediated alternative splicing of the kinesin family member 1B (KIF1B $\beta)$ gene [87]. LncRNAs may function in a manner more analogous to miRNAs; prostate-cancer-associated ncRNA transcript 1 (lncRNA PCAT-1) attenuates the expression of BRCA2 DNA repair associated (BRCA2) via the post-transcriptional repression of BRCA2 3' UTR [88].

\section{Secondary Structure of LncRNAs}

There is a link between lncRNA structure and function; accordingly, visualizing the architectural domains of lncRNAs is vital to understanding their function. One of the best studied lncRNAs is HOX transcript antisense intergenic RNA (HOTAIR), which has been demonstrated to repress tumor and metastasis suppressor genes. Somarowthu et al. [89] purified lncRNA HOTAIR in a homogeneous and monodispersed form to further determine its experimental secondary structure. LncRNA HOTAIR was found to be highly structured and composed of four independent architectural modules, two of which mediate the interaction of lncRNA HOTAIR with PRC2 and LSD1 (RE1-silencing transcription factor). The X-inactive specific transcript (XIST) $(\sim 18 \mathrm{~kb})$ represents one of the earliest discoveries of mammalian lncRNAs, with a well-defined role in the regulation of gene expression and $\mathrm{X}$-chromosome inactivation. The conformation of XIST has been explored by targeted structure-seq in mammalian cells [90]. The repeat A region of XIST is a functional element important for gene repression, whereas the repeat $C$ region mediates the interaction between XIST and proteins that anchor XIST to chromatin. The polyadenylated nuclear (PAN) lncRNA of Kaposi's sarcoma-associated herpes virus (KSHV) is produced during lytic infection and interacts with a variety of transcriptional regulators and chromatin modifiers. The structure of PAN lncRNA has been resolved and its binding motifs of LANA and ORF57 have been mapped [91]. PAN IncRNA folds into three branched domains and its $5^{\prime}$ Mta responsive element (MRE) region and $3^{\prime}$ expression and nuclear retention element (ENE) are identified in a larger structural context. A recent study identified the secondary structure of MALAT1, an important cancer-related lncRNA, in vitro and in various human cell lines [92]. In addition to providing protein/RNA-binding structural information, this study reveals that the structure of IncRNA MALAT1 can be perturbed by RNA modifications, mutations in cancer, and single-nucleotide polymorphisms. Moreover, recent studies have produced the three-dimensional structure of lncRNAs RepA and 7SK [93-95]. Collectively, a major feature of lncRNAs is their propensity to assume higher order structures that mediate diverse functions. The structural map of IncRNAs would help guide experiments and accelerate research that is focused on the molecular functions of lncRNA. 


\section{Dynamic Regulation of LncRNAs in Cancer Biology}

\subsection{Regulators of LncRNA Expression}

Recent studies have provided new insights into how lncRNA expression is regulated by various extra- and intra-cellular factors, including growth factors, hormones, DNA damage stress, transcription factors, and histone modifications (Table 4). In breast cancer, the epidermal growth factor (EGF) rapidly attenuates the expression of inhibiting metastasis (lncRNA LIMT) by enhancing histone deacetylation at its promoter region [96]. Growth factor deprivation or terminal differentiation upregulates incRNAs, termed quiescence-induced lncRNAs, which play important roles in H4K20me3-mediated chromatin compaction and transcriptional silencing [97]. Furthermore, hormone-regulated lncRNAs have been reported to be closely associated with hormone-dependent cancers. An androgen-responsive C-terminal binding protein 1 antisense (lncRNA CTBP1-AS) recruits the PTB-associated splicing factor (PSF) together with histone deacetylase (HDAC)/ SIN3 transcription regulator family member A (Sin3A) to the promoter of androgen receptor corepressor C-terminal binding protein 1 (CTBP1) and attenuates its expression in prostate cancer [98]. During the progression of renal cell carcinoma, estrogen receptor $\beta$ regulates $\operatorname{lncRNA}$ HOTAIR expression, further antagonizing the miR138/200c/204/217 function [99]. Niknafs et al. observed that Down syndrome cell adhesion molecule antisense (lncRNA DSCAM-AS1) is regulated by estrogen and mediates tumor progression in hormone-dependent breast cancer [100]. Following DNA damage, RNA polymerase II recruits the MRE11 (MRE11 homolog, double strand break repair nuclease)-RAD50 (RAD50 double strand break repair protein)-NBS1 (Nijmegen breakage syndrome 1) complex to double-strand break sites and synthesizes damage-inducing lncRNAs [101]. Recently, Kim et al. identified a role of MYC-regulated lncRNAs, named MYCLos, in cell cycle progression and colorectal tumorigenesis through regulating p15 and p21 [102]. Moreover, an antisense transcript of homeobox C10 (lncRNA HOXC-AS3) is obviously activated by increases of H3K4me3 and H3K27ac in gastric cancer, suggesting that lncRNAs can be regulated by histone modifications [103].

Table 4. Identification of lncRNA regulators.

\begin{tabular}{ccccc}
\hline Regulator & LncRNA & Regulatory Mechanism & Cancer Type & Ref \\
\hline EGF & LIMT & $\begin{array}{c}\text { Histone deacetylation of } \\
\text { promoter }\end{array}$ & Breast cancer & {$[96]$} \\
\hline Growth factors & $\begin{array}{c}\text { Quiescence-induced } \\
\text { lncRNAs }\end{array}$ & - & - & {$[97]$} \\
\hline Androgen & CTBP1-AS & AR-binding sites & Prostate cancer & {$[98]$} \\
\hline Estrogen receptor $\beta$ & HOTAIR & $\begin{array}{c}\text { Estrogen receptor } \beta \\
\text { binding }\end{array}$ & $\begin{array}{c}\text { Renal cell } \\
\text { carcinoma }\end{array}$ & {$[99]$} \\
\hline Oestrogen & DSCAM-AS1 & $\begin{array}{c}\text { Oestrogen receptor } \\
\text { binding }\end{array}$ & Breast cancer & {$[100]$} \\
\hline DNA damage stress & Damage-inducing & $\begin{array}{c}\text { MRE11-RAD50-NBS1 } \\
\text { complex recruitment }\end{array}$ & - & {$[101]$} \\
\hline MYC & MYCLNAs & Transcription regulation & Colorectal cancer & {$[102]$} \\
\hline Histone modification & HOXC-AS3 & Promotor modification & Gastric cancer & {$[103]$} \\
\hline
\end{tabular}

\subsection{LncRNA Turnover}

LncRNAs can regulate gene expression at the level of transcription by interference with mRNA expression, competition at genomic loci for transcription factors, or chromatin remodeling. Furthermore, lncRNAs influence pre-mRNA splicing, nuclear trafficking, and mRNA/protein degradation at the post-transcriptional level. Based on the emerging emphasis of lncRNAs on regulating gene profiles, the metabolism of lncRNA itself, termed lncRNA turnover, will likely be a vital aspect of its function. Several studies have provided new insights into lncRNA turnover, as follows. Decapping regulates the 
level or clearance of functional lncRNAs in different contexts because lncRNAs will be accumulated when decapping mRNA 2 (DCP2)-dependent decapping is blocked [104,105]. However, whether the regulation of lncRNA turnover by DCP2-dependent decapping contributes to cancer onset and progression requires further investigation. Moreover, IncRNA expression has been found to be more affected than mRNA expression by a deficiency in the poly(A)-binding protein nuclear 1 (PABPN1), which effectively promotes lncRNA degradation via a polyadenylation-dependent mechanism [106].

\subsection{Regulation of LncRNAs by Epitranscriptomics}

Both the structure and function of lncRNA will likely be affected by nucleoside/RNA modifications. 5-Methylcytidine $\left(\mathrm{m}^{5} \mathrm{C}\right)$, N6-methyladenosine $\left(\mathrm{m}^{6} \mathrm{~A}\right)$, and adenosine to inosine (A-to-I) editing have been documented in IncRNA modification [107]. LncRNAs XIST and HOTAIR harbor $\mathrm{m}^{5} \mathrm{C}$ modification sites in functionally relevant regions, which modulate their interactions with chromatin-modifying complexes [108]. One of the most abundant and dynamic mRNA modifications is $\mathrm{m}^{6} \mathrm{~A}$, in which a methyl group is attached to the N6 position of adenine [109,110]. Methylated RNA immunoprecipitation sequencing (MeRIP-seq) has been identified in more than $1500 \mathrm{~m}^{6} \mathrm{~A}$ modification sites in lncRNAs, accounting for $\sim 12 \%$ of the total $\mathrm{m}^{6} \mathrm{~A}$ peaks $[111,112]$. Hairpin-stem structures of lncRNA MALAT1 contain two $\mathrm{m}^{6} \mathrm{~A}$ residues, altering the secondary structure of MALAT1 to facilitate the binding of heterogeneous nuclear ribonucleoprotein C (hnRNPC) responsible for pre-mRNA processing [113,114]. The $\mathrm{m}^{6} \mathrm{~A}$ reader YTH N6-methyladenosine RNA binding protein 3 (YTHDF3) binds $\mathrm{m}^{6} \mathrm{~A}$-modified lncRNA GAS5 to promote its decay [71]. Interestingly, $\mathrm{m}^{6} \mathrm{~A}$ methyltransferase-like 3 (METTL3) depletion reduces the binding of DGCR8 to primary miRNA (pri-miRNAs) and leads to an accumulation of unprocessed pri-miRNAs $[115,116]$, indicating that $\mathrm{m}^{6} \mathrm{~A}$ can mark pri-miRNAs for processing. LncRNA transcripts can serve as pri-miRNA precursors; however, it is not clear whether $\mathrm{m}^{6} \mathrm{~A}$ can regulate $\ln \mathrm{RNA}$ processing. Hydrolytic deamination of adenosines (A) to inosines (I) is catalyzed by the adenosine deaminases acting on RNA (ADARs). Although A-to-I editing sites have been identified by RNA-Seq analysis in many lncRNAs, including MALAT1, XIST, and 7SK [117-119], the effects of A-to-I editing on particular IncRNA are not fully understood. A recent study suggests that prostate cancer antigen 3 (IncRNA PCA3) forms double-strand RNA with prune homolog 2 with the BCH domain (PRUNE2), which undergoes ADAR-dependent A-to-I RNA editing to regulate PRUNE2 levels [120].

\section{Diverse Mechanisms of LncRNAs: An Example from Autophagy in Cancer}

Autophagy is a highly regulated cellular degradation system, involving the sequestration of cytoplasmic components within the autophagosome, which is a transient double-membrane organelle. The autophagosome then fuses with the lysosome, resulting in the degradation of autophagic cargo to maintain cellular homeostasis [121,122]. The dysregulation of autophagy is involved in many human diseases, including cancers. Autophagy acts as a tumor suppressor by degrading the damaged proteins or organelles; however, autophagy sometimes promotes tumorigenesis exhibiting a survival/escape mechanism $[123,124]$. Here, we summarize the molecular mechanisms underlying IncRNA participants in autophagy regulatory networks, mainly through the regulating core machinery of autophagy (e.g., autophagy-related proteins and LC3) or autophagy-related proteins (e.g., mTOR, ULK1, and SIRT1) (Table 5).

LncRNA MALAT1 attenuates the inhibitory effect of miR-23b-3p on target autophagy-related 12 (ATG12), leading to chemo-induced autophagy and chemoresistance in gastric cancer [125]. In pancreatic ductal adenocarcinoma, IncRNA PVT1 acts as a sponge to regulate miR-20a-5p and thus affects the expression of unc-51-like-kinase 1 (ULK1), which is a key molecule of autophagy initiation [126]. Human maternally expressed gene 3 (lncRNA MEG3) promotes autophagy by protecting autophagy-related 3 (ATG3) from degradation in ovarian cancer [127]. Highly upregulated in liver cancer (lncRNA HULC) upregulates deubiquitinase ubiquitin specific peptidase 22 (USP22), protecting the ubiquitin-mediated degradation of a histone deacetylase Sirtuin 1 (SIRT1) protein to further trigger autophagy [128]. The antisense transcript of nicotinamide phosphoribosyltransferase 
(lncRNA NAMPT-AS) recruits POU class 2 homeobox 2 (POU2F2) to activate the transcription of $N A M P T$, in order to further promote tumor progression and autophagy in triple-negative breast cancer through the mTOR pathway [129]. LINC00470 regulates the methylation level of extracellular leucine-rich repeat and fibronectin type III domain containing 2 (ELFN2) by decreasing H3K27me3 occupancy in glioblastoma cell autophagy [130]. LncRNA MALAT1 mediates autophagic activation through regulating HuR-TIA1 (TIA1 cytotoxic granule-associated RNA binding protein), which is a major regulator of mRNA stability and translation [131]. The eosinophil granule ontogeny transcript (lncRNA EGOT) recruits heterogeneous nuclear ribonucleoprotein H1 (hnRNPH1) to enhance the alternative splicing of pre-inositol 1,4,5-trisphosphate receptor type 1 (ITPR1) to promote autophagy in human cancer [132].

Table 5. LncRNAs regulate 'autophagy in cancer' through diverse mechanisms.

\begin{tabular}{ccccc}
\hline LncRNA & Target & Mechanism & Cancer Type & Ref \\
\hline MALAT1 & ATG12, miR-23b-3p & ceRNA & Gastric cancer & {$[125]$} \\
PVT1 & ULK1, miR-20a-5p & ceRNA & Pancreatic cancer & {$[126]$} \\
MEG3 & ATG3 & Protein degradation & Ovarian cancer & {$[127]$} \\
HULC & SIRT1 & Protein degradation & Liver cancer & {$[128]$} \\
NAMPT-AS & POU2F2, mTOR & Scaffold of transcription factor & Breast cancer & {$[129]$} \\
LINC00470 & AurkA, eIF2 $\alpha$ & Epigenetic regulation & Glioblastoma & {$[130]$} \\
MALAT1 & HuR, TIA-1 & mRNA stability & Pancreatic cancer & {$[131]$} \\
EGOT & ITPR1 & Alternative splicing & Breast cancer & {$[132]$} \\
\hline
\end{tabular}

\section{Conclusions}

Studies conducted over the past 10 years have indicated that lncRNAs are implicated in a range of developmental processes and diseases, including cancer. In the current article, the diverse molecular mechanisms of lncRNAs during tumorigenesis have been comprehensively summarized, including competing ceRNA mechanisms, epigenetic regulation, decoy and scaffold mechanisms, mRNA and protein stability regulation, transcriptional and translational regulation, miRNA processing regulation, the architectural role of lncRNAs, and other uncommon mechanisms. Detailed elucidation of the role of lncRNAs and their regulatory mechanism will help to comprehensively understand the central dogma of DNA-RNA-protein, the evolution of complexity in higher eukaryotes, and the progression of cancers. Furthermore, determining the structure of lncRNAs and the complex of IncRNA is of significant importance for exploring the detailed mechanism of action of lncRNAs. Moreover, lncRNA itself is dynamically regulated in cancer cells, involving the regulation of its expression, turnover (metabolism), and modifications.

It will also be important to explore whether IncRNAs could be used in the diagnosis, prognosis, and therapeutics of cancer. Few lncRNAs are already implicated as biomarkers of cancer diagnosis and prognosis indexes in clinical trials (Table 6); however, there are still many challenges and validation is required for their clinical application. LncRNA-based cancer therapies are promising; however, at present, screening small-molecule libraries to identify candidate lncRNAs and the development of delivery strategies are required prior to clinical trials. A recent study functionalized IncRNAs in drug resistance by integrated genome-wide CRISPR activation of the lncRNA strategy, targeting 14,701 lncRNA genes, and found that growth arrest specific 6 antisense (lncRNA GAS6-AS2) triggers hyperactivation of the GAS6/TAM (TYRO3-AXL-MER2K) pathway, which is a known drug resistance mechanism in multiple cancers [133]. Novel identified lncRNAs, novel lncRNA modifications and turnover, and the novel functions and mechanisms of lncRNAs will be reported in the near future to further extend our understanding of the non-coding RNA world. An in-depth understanding of lncRNAs will not only shed light on their functions in cancer biology, but will open novel avenues for cancer diagnosis and therapeutics. 
Table 6. Application of LncRNAs in clinical trials.

\begin{tabular}{cccc}
\hline Identifier & Purpose & Application & Cancer Type \\
\hline NCT03830619 & $\begin{array}{c}\text { Evaluate the sensitivity/specificity of serum exosome lncRNA as a } \\
\text { diagnosis biomarker }\end{array}$ & Diagnosis & Lung cancer \\
\hline NCT04269746 & Evaluate the diagnostic value of lncRNA CCAT1 expression & Diagnosis & Colorectal cancer \\
\hline NCT03469544 & Evaluate the value of lncRNA HOTAIR and midkine as biomarkers & Diagnosis & Thyroid cancer \\
\hline NCT03738319 & Screen the candidate lncRNAs as biomarkers for the prognosis & Diagnosis & $\begin{array}{c}\text { Epithelia Ovarian } \\
\text { Cancer }\end{array}$ \\
\hline NCT03057171 & Evaluate the expression of lncRNA THRIL and PACER by \\
helicobacter pylori infection & Diagnosis & Stomach cancer \\
\hline NCT03000764 & Seek a molecular signature (e.g., lncRNA) of pathological \\
radiation-induced fibrosis & Diagnosis & Breast cancer \\
\hline NCT04288739 & $\begin{array}{c}\text { Detect the prognostic role of lncRNA XIST in acute myeloid } \\
\text { leukemia }\end{array}$ & Diagnosis & Hematologic cancer \\
\hline NCT03742869 & $\begin{array}{c}\text { Detect the expression of lncRNAs in uterine cervical } \\
\text { adenocarcinoma patients with and without HPV integration }\end{array}$ & Diagnosis & $\begin{array}{c}\text { Uterine cervical } \\
\text { adenocarcinoma }\end{array}$ \\
\hline NCT04269746 & $\begin{array}{l}\text { Validate the mRNA-lncRNA signature to predict the } \\
\text { efficacy/recurrence risk after a combination of chemotherapy drugs }\end{array}$ & Prognosis & $\begin{array}{c}\text { Triple-negative } \\
\text { breast cancer }\end{array}$ \\
\hline NCT03742856 & $\begin{array}{c}\text { Predict the invasiveness and tumorigenesis of cancer cells with } \\
\text { different FIGO stages and subtypes }\end{array}$ & Prognosis & $\begin{array}{c}\text { Epithelial ovarian } \\
\text { cancer }\end{array}$ \\
\hline NCT04010487 & $\begin{array}{c}\text { Predict the pathogenesis of the malignant transformation of } \\
\text { adenomyosis }\end{array}$ & Prognosis & \begin{tabular}{c} 
Endometrial cancer \\
\hline
\end{tabular}
\end{tabular}

Author Contributions: S.-R.C. conceived the review and X.-Z.Z. and H.L. undertook the initial research. All authors contributed to the final version. All authors have read and agreed to the published version of the manuscript.

Funding: This study is supported by "the Fundamental Research Funds for the Central Universities (2019NTST14)" and "Open Fund of Key Laboratory of Cell Proliferation and Regulation Biology, Ministry of Education".

Conflicts of Interest: The authors declare that there are no conflicts of interest.

\section{References}

1. Gottlieb, G. Normally occurring environmental and behavioral influences on gene activity: From central dogma to probabilistic epigenesis. Psychol. Rev. 1998, 105, 792-802. [CrossRef] [PubMed]

2. Venter, J.C.; Adams, M.D.; Myers, E.W.; Li, P.W.; Mural, R.J.; Sutton, G.G.; Smith, H.O.; Yandell, M.; Evans, C.A.; Holt, R.A.; et al. The sequence of the human genome. Science 2001, 291, 1304-1351. [CrossRef] [PubMed]

3. Lander, E.S.; Linton, L.M.; Birren, B.; Nusbaum, C.; Zody, M.C.; Baldwin, J.; Devon, K.; Dewar, K.; Doyle, M.; FitzHugh, W.; et al. Initial sequencing and analysis of the human genome. Nature 2001, 409, 860-921. [CrossRef] [PubMed]

4. Ma, L.; Bajic, V.B.; Zhang, Z. On the classification of long non-coding RNAs. Rna Biol. 2013, 10, 925-933. [CrossRef]

5. Shi, X.; Sun, M.; Liu, H.; Yao, Y.; Song, Y. Long non-coding RNAs: A new frontier in the study of human diseases. Cancer Lett. 2013, 339, 159-166. [CrossRef] [PubMed]

6. Memczak, S.; Jens, M.; Elefsinioti, A.; Torti, F.; Krueger, J.; Rybak, A.; Maier, L.; Mackowiak, S.D.; Gregersen, L.H.; Munschauer, M.; et al. Circular RNAs are a large class of animal RNAs with regulatory potency. Nature 2013, 495, 333-338. [CrossRef]

7. Enuka, Y.; Lauriola, M.; Feldman, M.E.; Sas-Chen, A.; Ulitsky, I.; Yarden, Y. Circular RNAs are long-lived and display only minimal early alterations in response to a growth factor. Nucleic Acids Res. 2016, 44, 1370-1383. [CrossRef]

8. Kondo, T.; Plaza, S.; Zanet, J.; Benrabah, E.; Valenti, P.; Hashimoto, Y.; Kobayashi, S.; Payre, F.; Kageyama, Y. Small peptides switch the transcriptional activity of Shavenbaby during Drosophila embryogenesis. Science 2010, 329, 336-339. [CrossRef] 
9. Ruiz-Orera, J.; Messeguer, X.; Subirana, J.A.; Alba, M.M. Long non-coding RNAs as a source of new peptides. eLife 2014, 3, e03523. [CrossRef]

10. Huang, J.Z.; Chen, M.; Chen, D.; Gao, X.C.; Zhu, S.; Huang, H.; Hu, M.; Zhu, H.; Yan, G.R. A peptide encoded by a putative lncRNA HOXB-AS3 suppresses colon cancer growth. Mol. Cell 2017, 68, 171-184.e6. [CrossRef]

11. Williamson, L.; Saponaro, M.; Boeing, S.; East, P.; Mitter, R.; Kantidakis, T.; Kelly, G.P.; Lobley, A.; Walker, J.; Spencer-Dene, B.; et al. UV irradiation induces a non-coding RNA that functionally opposes the protein encoded by the same gene. Cell 2017, 168, 843-855.e813. [CrossRef] [PubMed]

12. Grelet, S.; Link, L.A.; Howley, B.; Obellianne, C.; Palanisamy, V.; Gangaraju, V.K.; Diehl, J.A.; Howe, P.H. A regulated PNUTS mRNA to lncRNA splice switch mediates EMT and tumour progression. Nat. Cell Biol. 2017, 19, 1105-1115. [CrossRef] [PubMed]

13. Song, H.; Ramus, S.J.; Tyrer, J.; Bolton, K.L.; Gentry-Maharaj, A.; Wozniak, E.; Anton-Culver, H.; Chang-Claude, J.; Cramer, D.W.; DiCioccio, R.; et al. A genome-wide association study identifies a new ovarian cancer susceptibility locus on 9p22.2. Nat. Genet. 2009, 41, 996-1000. [CrossRef] [PubMed]

14. Bolton, K.L.; Tyrer, J.; Song, H.; Ramus, S.J.; Notaridou, M.; Jones, C.; Sher, T.; Gentry-Maharaj, A.; Wozniak, E.; Tsai, Y.Y.; et al. Common variants at 19p13 are associated with susceptibility to ovarian cancer. Nat. Genet. 2010, 42, 880-884. [CrossRef]

15. Pharoah, P.D.; Tsai, Y.Y.; Ramus, S.J.; Phelan, C.M.; Goode, E.L.; Lawrenson, K.; Buckley, M.; Fridley, B.L.; Tyrer, J.P.; Shen, H.; et al. GWAS meta-analysis and replication identifies three new susceptibility loci for ovarian cancer. Nat. Genet. 2013, 45, 362-370. [CrossRef]

16. Kuchenbaecker, K.B.; Ramus, S.J.; Tyrer, J.; Lee, A.; Shen, H.C.; Beesley, J.; Lawrenson, K.; McGuffog, L.; Healey, S.; Lee, J.M.; et al. Identification of six new susceptibility loci for invasive epithelial ovarian cancer. Nat. Genet. 2015, 47, 164-171. [CrossRef]

17. Kelemen, L.E.; Lawrenson, K.; Tyrer, J.; Li, Q.; Lee, J.M.; Seo, J.H.; Phelan, C.M.; Beesley, J.; Chen, X.; Spindler, T.J.; et al. Genome-wide significant risk associations for mucinous ovarian carcinoma. Nat. Genet. 2015, 47, 888-897. [CrossRef]

18. Phelan, C.M.; Kuchenbaecker, K.B.; Tyrer, J.P.; Kar, S.P.; Lawrenson, K.; Winham, S.J.; Dennis, J.; Pirie, A.; Riggan, M.J.; Chornokur, G.; et al. Identification of 12 new susceptibility loci for different histotypes of epithelial ovarian cancer. Nat. Genet. 2017, 49, 680-691. [CrossRef]

19. Lu, Y.; Beeghly-Fadiel, A.; Wu, L.; Guo, X.; Li, B.; Schildkraut, J.M.; Im, H.K.; Chen, Y.A.; Permuth, J.B.; Reid, B.M.; et al. A transcriptome-wide association study among 97,898 women to identify candidate susceptibility genes for epithelial ovarian cancer risk. Cancer Res. 2018, 78, 5419-5430. [CrossRef]

20. Guo, H.; Ahmed, M.; Zhang, F.; Yao, C.Q.; Li, S.; Liang, Y.; Hua, J.; Soares, F.; Sun, Y.; Langstein, J.; et al. Modulation of long noncoding RNAs by risk SNPs underlying genetic predispositions to prostate cancer. Nat. Genet. 2016, 48, 1142-1150. [CrossRef]

21. Betts, J.A.; Moradi Marjaneh, M.; Al-Ejeh, F.; Lim, Y.C.; Shi, W.; Sivakumaran, H.; Tropee, R.; Patch, A.M.; Clark, M.B.; Bartonicek, N.; et al. Long noncoding RNAs CUPID1 and CUPID2 mediate breast cancer risk at 11q13 by modulating the response to DNA damage. Am. J. Hum. Genet. 2017, 101, 255-266. [CrossRef] [PubMed]

22. Ali, M.M.; Akhade, V.S.; Kosalai, S.T.; Subhash, S.; Statello, L.; Meryet-Figuiere, M.; Abrahamsson, J.; Mondal, T.; Kanduri, C. PAN-cancer analysis of S-phase enriched lncRNAs identifies oncogenic drivers and biomarkers. Nat. Commun. 2018, 9, 883. [CrossRef] [PubMed]

23. Garzon, R.; Volinia, S.; Papaioannou, D.; Nicolet, D.; Kohlschmidt, J.; Yan, P.S.; Mrozek, K.; Bucci, D.; Carroll, A.J.; Baer, M.R.; et al. Expression and prognostic impact of lncRNAs in acute myeloid leukemia. Proc. Natl. Acad. Sci. USA 2014, 111, 18679-18684. [CrossRef] [PubMed]

24. Wang, Y.; Wang, Z.; Xu, J.; Li, J.; Li, S.; Zhang, M.; Yang, D. Systematic identification of non-coding pharmacogenomic landscape in cancer. Nat. Commun. 2018, 9, 3192. [CrossRef]

25. Salmena, L.; Poliseno, L.; Tay, Y.; Kats, L.; Pandolfi, P.P. A ceRNA hypothesis: The Rosetta Stone of a hidden RNA language? Cell 2011, 146, 353-358. [CrossRef]

26. Thomson, D.W.; Dinger, M.E. Endogenous microRNA sponges: evidence and controversy. Nat. Rev. Genet. 2016, 17, 272-283. [CrossRef]

27. Poliseno, L.; Salmena, L.; Zhang, J.; Carver, B.; Haveman, W.J.; Pandolfi, P.P. A coding-independent function of gene and pseudogene mRNAs regulates tumour biology. Nature 2010, 465, 1033-1038. [CrossRef] 
28. Lu, W.; Zhang, H.; Niu, Y.; Wu, Y.; Sun, W.; Li, H.; Kong, J.; Ding, K.; Shen, H.M.; Wu, H.; et al. Long non-coding RNA linc00673 regulated non-small cell lung cancer proliferation, migration, invasion and epithelial mesenchymal transition by sponging miR-150-5p. Mol. Cancer 2017, 16, 118. [CrossRef]

29. Zhu, K.P.; Ma, X.L.; Zhang, C.L. LncRNA ODRUL Contributes to Osteosarcoma Progression through the miR-3182/MMP2 Axis. Mol. Ther. J. Am. Soc. Gene Ther. 2017, 25, 2383-2393. [CrossRef]

30. Chen, X.; Chen, Z.; Yu, S.; Nie, F.; Yan, S.; Ma, P.; Chen, Q.; Wei, C.; Fu, H.; Xu, T.; et al. Long noncoding RNA LINC01234 functions as a competing endogenous RNA to regulate CBFB expression by sponging miR-204-5p in gastric cancer. Clin. Cancer Res. Off. J. Am. Assoc. Cancer Res. 2018, 24, 2002-2014. [CrossRef]

31. Zhang, G.; Li, S.; Lu, J.; Ge, Y.; Wang, Q.; Ma, G.; Zhao, Q.; Wu, D.; Gong, W.; Du, M.; et al. LncRNA MT1JP functions as a ceRNA in regulating FBXW7 through competitively binding to miR-92a-3p in gastric cancer. Mol. Cancer 2018, 17, 87. [CrossRef] [PubMed]

32. Luo, Y.; Chen, J.J.; Lv, Q.; Qin, J.; Huang, Y.Z.; Yu, M.H.; Zhong, M. Long non-coding RNA NEAT1 promotes colorectal cancer progression by competitively binding miR-34a with SIRT1 and enhancing the Wnt/beta-catenin signaling pathway. Cancer Lett. 2019, 440-441, 11-22. [CrossRef]

33. Li, W.; Ma, S.; Bai, X.; Pan, W.; Ai, L.; Tan, W. Long noncoding RNA WDFY3-AS2 suppresses tumor progression by acting as a competing endogenous RNA of microRNA-18a in ovarian cancer. J. Cell. Physiol. 2019. [CrossRef] [PubMed]

34. Zanet, J.; Benrabah, E.; Li, T.; Pelissier-Monier, A.; Chanut-Delalande, H.; Ronsin, B.; Bellen, H.J.; Payre, F.; Plaza, S. Pri sORF peptides induce selective proteasome-mediated protein processing. Science 2015, 349, 1356-1358. [CrossRef] [PubMed]

35. Bazin, J.; Baerenfaller, K.; Gosai, S.J.; Gregory, B.D.; Crespi, M.; Bailey-Serres, J. Global analysis of ribosome-associated noncoding RNAs unveils new modes of translational regulation. Proc. Natl. Acad. Sci. USA 2017, 114, E10018-E10027. [CrossRef]

36. Pan, J.; Meng, X.; Jiang, N.; Jin, X.; Zhou, C.; Xu, D.; Gong, Z. Insights into the Noncoding RNA-encoded Peptides. Protein Pept. Lett. 2018, 25, 720-727. [CrossRef]

37. Wang, J.; Zhu, S.; Meng, N.; He, Y.; Lu, R.; Yan, G.R. ncRNA-Encoded Peptides or Proteins and Cancer. Mol. Ther. J. Am. Soc. Gene Ther. 2019, 27, 1718-1725. [CrossRef]

38. Denzler, R.; Agarwal, V.; Stefano, J.; Bartel, D.P.; Stoffel, M. Assessing the ceRNA hypothesis with quantitative measurements of miRNA and target abundance. Mol. Cell 2014, 54, 766-776. [CrossRef]

39. Yuan, Y.; Liu, B.; Xie, P.; Zhang, M.Q.; Li, Y.D.; Xie, Z.; Wang, X.W. Model-guided quantitative analysis of microRNA-mediated regulation on competing endogenous RNAs using a synthetic gene circuit. Proc. Natl. Acad. Sci. USA 2015, 112, 3158-3163. [CrossRef]

40. Aguilo, F.; Zhou, M.M.; Walsh, M.J. Long noncoding RNA, polycomb, and the ghosts haunting INK4b-ARF-INK4a expression. Cancer Res. 2011, 71, 5365-5369. [CrossRef]

41. Wang, H.; Wang, L.; Erdjument-Bromage, H.; Vidal, M.; Tempst, P.; Jones, R.S.; Zhang, Y. Role of histone H2A ubiquitination in Polycomb silencing. Nature 2004, 431, 873-878. [CrossRef]

42. Cao, R.; Wang, L.; Wang, H.; Xia, L.; Erdjument-Bromage, H.; Tempst, P.; Jones, R.S.; Zhang, Y. Role of histone H3 lysine 27 methylation in Polycomb-group silencing. Science 2002, 298, 1039-1043. [CrossRef]

43. Khalil, A.M.; Guttman, M.; Huarte, M.; Garber, M.; Raj, A.; Rivea Morales, D.; Thomas, K.; Presser, A.; Bernstein, B.E.; van Oudenaarden, A.; et al. Many human large intergenic noncoding RNAs associate with chromatin-modifying complexes and affect gene expression. Proc. Natl. Acad. Sci. USA 2009, 106, 11667-11672. [CrossRef]

44. Zhao, J.; Ohsumi, T.K.; Kung, J.T.; Ogawa, Y.; Grau, D.J.; Sarma, K.; Song, J.J.; Kingston, R.E.; Borowsky, M.; Lee, J.T. Genome-wide identification of polycomb-associated RNAs by RIP-seq. Mol. Cell 2010, 40, 939-953. [CrossRef]

45. Yap, K.L.; Li, S.; Munoz-Cabello, A.M.; Raguz, S.; Zeng, L.; Mujtaba, S.; Gil, J.; Walsh, M.J.; Zhou, M.M. Molecular interplay of the noncoding RNA ANRIL and methylated histone H3 lysine 27 by polycomb CBX7 in transcriptional silencing of INK4a. Mol. Cell 2010, 38, 662-674. [CrossRef]

46. Rinn, J.L.; Kertesz, M.; Wang, J.K.; Squazzo, S.L.; Xu, X.; Brugmann, S.A.; Goodnough, L.H.; Helms, J.A.; Farnham, P.J.; Segal, E.; et al. Functional demarcation of active and silent chromatin domains in human HOX loci by noncoding RNAs. Cell 2007, 129, 1311-1323. [CrossRef] 
47. Kong, R.; Zhang, E.B.; Yin, D.D.; You, L.H.; Xu, T.P.; Chen, W.M.; Xia, R.; Wan, L.; Sun, M.; Wang, Z.X.; et al. Long noncoding RNA PVT1 indicates a poor prognosis of gastric cancer and promotes cell proliferation through epigenetically regulating p15 and p16. Mol. Cancer 2015, 14, 82. [CrossRef]

48. Marin-Bejar, O.; Mas, A.M.; Gonzalez, J.; Martinez, D.; Athie, A.; Morales, X.; Galduroz, M.; Raimondi, I.; Grossi, E.; Guo, S.; et al. The human lncRNA LINC-PINT inhibits tumor cell invasion through a highly conserved sequence element. Genome Biol. 2017, 18, 202. [CrossRef]

49. Gonzalez, I.; Munita, R.; Agirre, E.; Dittmer, T.A.; Gysling, K.; Misteli, T.; Luco, R.F. A lncRNA regulates alternative splicing via establishment of a splicing-specific chromatin signature. Nat. Struct. Mol. Biol. 2015, 22, 370-376. [CrossRef]

50. Luco, R.F.; Pan, Q.; Tominaga, K.; Blencowe, B.J.; Pereira-Smith, O.M.; Misteli, T. Regulation of alternative splicing by histone modifications. Science 2010, 327, 996-1000. [CrossRef]

51. Gu, P.; Chen, X.; Xie, R.; Han, J.; Xie, W.; Wang, B.; Dong, W.; Chen, C.; Yang, M.; Jiang, J.; et al. IncRNA HOXD-AS1 regulates proliferation and chemo-resistance of castration-resistant prostate cancer via recruiting WDR5. Mol. Ther. J. Am. Soc. Gene Ther. 2017, 25, 1959-1973. [CrossRef] [PubMed]

52. Ma, M.; Zhang, Y.; Weng, M.; Hu, Y.; Xuan, Y.; Hu, Y.; Lv, K. IncRNA GCAWKR promotes gastric cancer development by scaffolding the chromatin modification factors WDR5 and KAT2A. Mol. Ther. J. Am. Soc. Gene Ther. 2018, 26, 2658-2668. [CrossRef] [PubMed]

53. Pan, W.; Zhang, N.; Liu, W.; Liu, J.; Zhou, L.; Liu, Y.; Yang, M. The long noncoding RNA GAS8-AS1 suppresses hepatocarcinogenesis by epigenetically activating the tumor suppressor GAS8. J. Biol. Chem. 2018, 293, 17154-17165. [CrossRef]

54. Chen, Z.; Gao, Y.; Yao, L.; Liu, Y.; Huang, L.; Yan, Z.; Zhao, W.; Zhu, P.; Weng, H. LncFZD6 initiates Wnt/beta-catenin and liver TIC self-renewal through BRG1-mediated FZD6 transcriptional activation. Oncogene 2018, 37, 3098-3112. [CrossRef]

55. Wang, Y.Q.; Jiang, D.M.; Hu, S.S.; Zhao, L.; Wang, L.; Yang, M.H.; Ai, M.L.; Jiang, H.J.; Han, Y.; Ding, Y.Q.; et al. SATB2-AS1 suppresses colorectal carcinoma aggressiveness by inhibiting SATB2-dependent Snail transcription and epithelial-mesenchymal transition. Cancer Res. 2019, 79, 3542-3556. [CrossRef]

56. Wang, Y.; Zhu, P.; Luo, J.; Wang, J.; Liu, Z.; Wu, W.; Du, Y.; Ye, B.; Wang, D.; He, L.; et al. LncRNA HAND2-AS1 promotes liver cancer stem cell self-renewal via BMP signaling. EMBO J. 2019, 38, e101110. [CrossRef]

57. Shao, M.; Yang, Q.; Zhu, W.; Jin, H.; Wang, J.; Song, J.; Kong, Y.; Lv, X. LncHOXA10 drives liver TICs self-renewal and tumorigenesis via HOXA10 transcription activation. Mol. Cancer 2018, 17, 173. [CrossRef]

58. Miao, H.; Wang, L.; Zhan, H.; Dai, J.; Chang, Y.; Wu, F.; Liu, T.; Liu, Z.; Gao, C.; Li, L.; et al. A long noncoding RNA distributed in both nucleus and cytoplasm operates in the PYCARD-regulated apoptosis by coordinating the epigenetic and translational regulation. PLoS Genet. 2019, 15, e1008144. [CrossRef]

59. Wang, K.C.; Yang, Y.W.; Liu, B.; Sanyal, A.; Corces-Zimmerman, R.; Chen, Y.; Lajoie, B.R.; Protacio, A.; Flynn, R.A.; Gupta, R.A.; et al. A long noncoding RNA maintains active chromatin to coordinate homeotic gene expression. Nature 2011, 472, 120-124. [CrossRef]

60. Yang, Y.W.; Flynn, R.A.; Chen, Y.; Qu, K.; Wan, B.; Wang, K.C.; Lei, M.; Chang, H.Y. Essential role of lncRNA binding for WDR5 maintenance of active chromatin and embryonic stem cell pluripotency. eLife 2014, 3, e02046. [CrossRef]

61. Krawczyk, M.; Emerson, B.M. p50-associated COX-2 extragenic RNA (PACER) activates COX-2 gene expression by occluding repressive NF-kappaB complexes. eLife 2014, 3, e01776. [CrossRef]

62. Ji, Q.; Zhang, L.; Liu, X.; Zhou, L.; Wang, W.; Han, Z.; Sui, H.; Tang, Y.; Wang, Y.; Liu, N.; et al. Long non-coding RNA MALAT1 promotes tumour growth and metastasis in colorectal cancer through binding to SFPQ and releasing oncogene PTBP2 from SFPQ/PTBP2 complex. Br. J. Cancer 2014, 111, 736-748. [CrossRef]

63. Sang, B.; Zhang, Y.Y.; Guo, S.T.; Kong, L.F.; Cheng, Q.; Liu, G.Z.; Thorne, R.F.; Zhang, X.D.; Jin, L.; Wu, M. Dual functions for OVAAL in initiation of RAF/MEK/ERK prosurvival signals and evasion of p27-mediated cellular senescence. Proc. Natl. Acad. Sci. USA 2018, 115, E11661-E11670. [CrossRef]

64. Fan, J.; Xing, Y.; Wen, X.; Jia, R.; Ni, H.; He, J.; Ding, X.; Pan, H.; Qian, G.; Ge, S.; et al. Long non-coding RNA ROR decoys gene-specific histone methylation to promote tumorigenesis. Genome Biol. 2015, 16, 139. [CrossRef] 
65. Cheadle, C.; Fan, J.; Cho-Chung, Y.S.; Werner, T.; Ray, J.; Do, L.; Gorospe, M.; Becker, K.G. Stability regulation of mRNA and the control of gene expression. Ann. New York Acad. Sci. 2005, 1058, 196-204. [CrossRef]

66. Kumar, P.P.; Emechebe, U.; Smith, R.; Franklin, S.; Moore, B.; Yandell, M.; Lessnick, S.L.; Moon, A.M. Coordinated control of senescence by lncRNA and a novel T-box3 co-repressor complex. eLife 2014, 3. [CrossRef]

67. Jadaliha, M.; Gholamalamdari, O.; Tang, W.; Zhang, Y.; Petracovici, A.; Hao, Q.; Tariq, A.; Kim, T.G.; Holton, S.E.; Singh, D.K.; et al. A natural antisense lncRNA controls breast cancer progression by promoting tumor suppressor gene mRNA stability. PLoS Genet. 2018, 14, e1007802. [CrossRef]

68. Tseng, Y.Y.; Moriarity, B.S.; Gong, W.; Akiyama, R.; Tiwari, A.; Kawakami, H.; Ronning, P.; Reuland, B.; Guenther, K.; Beadnell, T.C.; et al. PVT1 dependence in cancer with MYC copy-number increase. Nature 2014, 512, 82-86. [CrossRef]

69. Lin, A.; Li, C.; Xing, Z.; Hu, Q.; Liang, K.; Han, L.; Wang, C.; Hawke, D.H.; Wang, S.; Zhang, Y.; et al. The LINK-A lncRNA activates normoxic HIF1alpha signalling in triple-negative breast cancer. Nat. Cell Biol. 2016, 18, 213-224. [CrossRef]

70. Li, Z.; Hou, P.; Fan, D.; Dong, M.; Ma, M.; Li, H.; Yao, R.; Li, Y.; Wang, G.; Geng, P.; et al. The degradation of EZH2 mediated by lncRNA ANCR attenuated the invasion and metastasis of breast cancer. Cell Death Differ. 2017, 24, 59-71. [CrossRef]

71. Ni, W.; Yao, S.; Zhou, Y.; Liu, Y.; Huang, P.; Zhou, A.; Liu, J.; Che, L.; Li, J. Long noncoding RNA GAS5 inhibits progression of colorectal cancer by interacting with and triggering YAP phosphorylation and degradation and is negatively regulated by the $\mathrm{m}(6) \mathrm{A}$ reader YTHDF3. Mol. Cancer 2019, 18, 143. [CrossRef]

72. Gu, P.; Chen, X.; Xie, R.; Xie, W.; Huang, L.; Dong, W.; Han, J.; Liu, X.; Shen, J.; Huang, J.; et al. A novel AR translational regulator lncRNA LBCS inhibits castration resistance of prostate cancer. Mol. Cancer 2019, 18, 109. [CrossRef]

73. Saayman, S.M.; Ackley, A.; Burdach, J.; Clemson, M.; Gruenert, D.C.; Tachikawa, K.; Chivukula, P.; Weinberg, M.S.; Morris, K.V. Long non-coding RNA BGas regulates the cystic fibrosis transmembrane conductance regulator. Mol. Ther. J. Am. Soc. Gene Ther. 2016, 24, 1351-1357. [CrossRef]

74. Di Cecilia, S.; Zhang, F.; Sancho, A.; Li, S.; Aguilo, F.; Sun, Y.; Rengasamy, M.; Zhang, W.; Del Vecchio, L.; Salvatore, F.; et al. RBM5-AS1 is critical for self-renewal of colon cancer stem-like cells. Cancer Res. 2016, 76, 5615-5627. [CrossRef]

75. Lingadahalli, S.; Jadhao, S.; Sung, Y.Y.; Chen, M.; Hu, L.; Chen, X.; Cheung, E. Novel lncRNA LINC00844 regulates prostate cancer cell migration and invasion through AR signaling. Mol. Cancer Res. Mcr 2018, 16, 1865-1878. [CrossRef]

76. Wang, K.; Sun, T.; Li, N.; Wang, Y.; Wang, J.X.; Zhou, L.Y.; Long, B.; Liu, C.Y.; Liu, F.; Li, P.F. MDRL lncRNA regulates the processing of miR-484 primary transcript by targeting miR-361. PLoS Genet. 2014, 10, e1004467. [CrossRef]

77. Tian, T.; Lv, X.; Pan, G.; Lu, Y.; Chen, W.; He, W.; Lei, X.; Zhang, H.; Liu, M.; Sun, S.; et al. Long Noncoding RNA MPRL promotes mitochondrial fission and cisplatin chemosensitivity via disruption of pre-miRNA processing. Clin. Cancer Res. Off. J. Am. Assoc. Cancer Res. 2019, 25, 3673-3688. [CrossRef]

78. Chen, L.L.; Carmichael, G.G. Altered nuclear retention of mRNAs containing inverted repeats in human embryonic stem cells: Functional role of a nuclear noncoding RNA. Mol. Cell 2009, 35, 467-478. [CrossRef]

79. Clemson, C.M.; Hutchinson, J.N.; Sara, S.A.; Ensminger, A.W.; Fox, A.H.; Chess, A.; Lawrence, J.B. An architectural role for a nuclear noncoding RNA: NEAT1 RNA is essential for the structure of paraspeckles. Mol. Cell 2009, 33, 717-726. [CrossRef]

80. Sasaki, Y.T.; Ideue, T.; Sano, M.; Mituyama, T.; Hirose, T. MENepsilon/beta noncoding RNAs are essential for structural integrity of nuclear paraspeckles. Proc. Natl. Acad. Sci. USA 2009, 106, 2525-2530. [CrossRef]

81. Choudhry, H.; Albukhari, A.; Morotti, M.; Haider, S.; Moralli, D.; Smythies, J.; Schodel, J.; Green, C.M.; Camps, C.; Buffa, F.; et al. Tumor hypoxia induces nuclear paraspeckle formation through HIF-2alpha dependent transcriptional activation of NEAT1 leading to cancer cell survival. Oncogene 2015, 34, 4482-4490. [CrossRef]

82. Adriaens, C.; Standaert, L.; Barra, J.; Latil, M.; Verfaillie, A.; Kalev, P.; Boeckx, B.; Wijnhoven, P.W.; Radaelli, E.; Vermi, W.; et al. p53 induces formation of NEAT1 lncRNA-containing paraspeckles that modulate replication stress response and chemosensitivity. Nat. Med. 2016, 22, 861-868. [CrossRef] [PubMed] 
83. Wang, S.; Zhang, Q.; Wang, Q.; Shen, Q.; Chen, X.; Li, Z.; Zhou, Y.; Hou, J.; Xu, B.; Li, N.; et al. NEAT1 paraspeckle promotes human hepatocellular carcinoma progression by strengthening IL-6/STAT3 signaling. Oncoimmunology 2018, 7, e1503913. [CrossRef] [PubMed]

84. Wang, Y.; Hu, S.B.; Wang, M.R.; Yao, R.W.; Wu, D.; Yang, L.; Chen, L.L. Genome-wide screening of NEAT1 regulators reveals cross-regulation between paraspeckles and mitochondria. Nat. Cell Biol. 2018, 20, 1145-1158. [CrossRef]

85. Cho, S.W.; Xu, J.; Sun, R.; Mumbach, M.R.; Carter, A.C.; Chen, Y.G.; Yost, K.E.; Kim, J.; He, J.; Nevins, S.A.; et al. Promoter of lncRNA gene PVT1 is a tumor-suppressor DNA boundary element. Cell 2018, 173, 1398-1412.e22. [CrossRef] [PubMed]

86. Werner, M.S.; Sullivan, M.A.; Shah, R.N.; Nadadur, R.D.; Grzybowski, A.T.; Galat, V.; Moskowitz, I.P.; Ruthenburg, A.J. Chromatin-enriched lncRNAs can act as cell-type specific activators of proximal gene transcription. Nat. Struct. Mol. Biol. 2017, 24, 596-603. [CrossRef] [PubMed]

87. Gordon, M.A.; Babbs, B.; Cochrane, D.R.; Bitler, B.G.; Richer, J.K. The long non-coding RNA MALAT1 promotes ovarian cancer progression by regulating RBFOX2-mediated alternative splicing. Mol. Carcinog. 2019, 58, 196-205. [CrossRef]

88. Prensner, J.R.; Chen, W.; Iyer, M.K.; Cao, Q.; Ma, T.; Han, S.; Sahu, A.; Malik, R.; Wilder-Romans, K.; Navone, N.; et al. PCAT-1, a long noncoding RNA, regulates BRCA2 and controls homologous recombination in cancer. Cancer Res. 2014, 74, 1651-1660. [CrossRef]

89. Somarowthu, S.; Legiewicz, M.; Chillón, I.; Marcia, M.; Liu, F.; Pyle, A.M. HOTAIR forms an intricate and modular secondary structure. Mol. Cell 2015, 58, 353-361. [CrossRef]

90. Fang, R.; Moss, W.N.; Rutenberg-Schoenberg, M.; Simon, M.D. Probing Xist RNA structure in cells using targeted structure-seq. PLoS Genet. 2015, 11, e100566858. [CrossRef]

91. Sztuba-Solinska, J.; Rausch, J.W.; Smith, R.; Miller, J.T.; Whitby, D.; Le Grice, S.F.J. Kaposi's sarcoma-associated herpesvirus polyadenylated nuclear RNA: A structural scaffold for nuclear, cytoplasmic and viral proteins. Nucleic Acids Res. 2017, 45, 6805-6821. [CrossRef] [PubMed]

92. McCown, P.J.; Wang, M.C.; Jaeger, L.; Brown, J.A. Secondary structural model of human MALAT1 reveals multiple structure-function relationships. Int. J. Mol. Sci. 2019, 20, 5610. [CrossRef] [PubMed]

93. Liu, F.; Somarowthu, S.; Pyle, A.M. Visualizing the secondary and tertiary architectural domains of lncRNA RepA. Nat. Chem. Biol. 2017, 13, 282-289. [CrossRef] [PubMed]

94. Martinez-Zapien, D.; Legrand, P.; McEwen, A.G.; Proux, F.; Cragnolini, T.; Pasquali, S.; Dock-Bregeon, A.C. The crystal structure of the 5 functional domain of the transcription riboregulator 7SK. Nucleic Acids Res. 2017, 45, 3568-3579. [CrossRef]

95. Eichhorn, C.D.; Yang, Y.; Repeta, L.; Feigon, J. Structural basis for recognition of human 7SK long noncoding RNA by the La-related protein Larp7. Proc. Natl. Acad. Sci. USA 2018, 115, E6457-E6466. [CrossRef] [PubMed]

96. Sas-Chen, A.; Aure, M.R.; Leibovich, L.; Carvalho, S.; Enuka, Y.; Korner, C.; Polycarpou-Schwarz, M.; Lavi, S.; Nevo, N.; Kuznetsov, Y.; et al. LIMT is a novel metastasis inhibiting lncRNA suppressed by EGF and downregulated in aggressive breast cancer. EMBO Mol. Med. 2016, 8, 1052-1064. [CrossRef]

97. Bierhoff, H.; Dammert, M.A.; Brocks, D.; Dambacher, S.; Schotta, G.; Grummt, I. Quiescence-induced LncRNAs trigger H4K20 trimethylation and transcriptional silencing. Mol. Cell 2014, 54, 675-682. [CrossRef]

98. Takayama, K.; Horie-Inoue, K.; Katayama, S.; Suzuki, T.; Tsutsumi, S.; Ikeda, K.; Urano, T.; Fujimura, T.; Takagi, K.; Takahashi, S.; et al. Androgen-responsive long noncoding RNA CTBP1-AS promotes prostate cancer. EMBO J. 2013, 32, 1665-1680. [CrossRef]

99. Ding, J.; Yeh, C.R.; Sun, Y.; Lin, C.; Chou, J.; Ou, Z.; Chang, C.; Qi, J.; Yeh, S. Estrogen receptor beta promotes renal cell carcinoma progression via regulating LncRNA HOTAIR-miR-138/200c/204/217 associated CeRNA network. Oncogene 2018, 37, 5037-5053. [CrossRef]

100. Niknafs, Y.S.; Han, S.; Ma, T.; Speers, C.; Zhang, C.; Wilder-Romans, K.; Iyer, M.K.; Pitchiaya, S.; Malik, R.; Hosono, Y.; et al. The lncRNA landscape of breast cancer reveals a role for DSCAM-AS1 in breast cancer progression. Nat. Commun. 2016, 7, 12791. [CrossRef]

101. Michelini, F.; Pitchiaya, S.; Vitelli, V.; Sharma, S.; Gioia, U.; Pessina, F.; Cabrini, M.; Wang, Y.; Capozzo, I.; Iannelli, F.; et al. Damage-induced lncRNAs control the DNA damage response through interaction with DDRNAs at individual double-strand breaks. Nat. Cell Biol. 2017, 19, 1400-1411. [CrossRef] 
102. Kim, T.; Jeon, Y.J.; Cui, R.; Lee, J.H.; Peng, Y.; Kim, S.H.; Tili, E.; Alder, H.; Croce, C.M. Role of MYC-regulated long noncoding RNAs in cell cycle regulation and tumorigenesis. J. Natl. Cancer Inst. 2015, 107. [CrossRef]

103. Zhang, E.; He, X.; Zhang, C.; Su, J.; Lu, X.; Si, X.; Chen, J.; Yin, D.; Han, L.; De, W. A novel long noncoding RNA HOXC-AS3 mediates tumorigenesis of gastric cancer by binding to YBX1. Genome Biol. 2018, 19, 154. [CrossRef]

104. Geisler, S.; Lojek, L.; Khalil, A.M.; Baker, K.E.; Coller, J. Decapping of long noncoding RNAs regulates inducible genes. Mol. Cell 2012, 45, 279-291. [CrossRef]

105. Ramaiah, M.; Shum, E.Y.; Wilkinson, M.F. How to activate a gene: Decap its associated noncoding RNA. Mol. Cell 2012, 45, 271-273. [CrossRef]

106. Beaulieu, Y.B.; Kleinman, C.L.; Landry-Voyer, A.M.; Majewski, J.; Bachand, F. Polyadenylation-dependent control of long noncoding RNA expression by the poly(A)-binding protein nuclear 1. PLoS Genet. 2012, 8, e1003078. [CrossRef]

107. Shafik, A.; Schumann, U.; Evers, M.; Sibbritt, T.; Preiss, T. The emerging epitranscriptomics of long noncoding RNAs. Biochim. Et Biophys. Acta 2016, 1859, 59-70. [CrossRef]

108. Amort, T.; Souliere, M.F.; Wille, A.; Jia, X.Y.; Fiegl, H.; Worle, H.; Micura, R.; Lusser, A. Long non-coding RNAs as targets for cytosine methylation. Rna Biol. 2013, 10, 1003-1008. [CrossRef]

109. Fu, Y.; Dominissini, D.; Rechavi, G.; He, C. Gene expression regulation mediated through reversible m(6)A RNA methylation. Nat. Rev. Genet. 2014, 15, 293-306. [CrossRef]

110. Meyer, K.D.; Jaffrey, S.R. The dynamic epitranscriptome: N6-methyladenosine and gene expression control. Nat. Rev. Mol. Cell Biol. 2014, 15, 313-326. [CrossRef]

111. Meyer, K.D.; Saletore, Y.; Zumbo, P.; Elemento, O.; Mason, C.E.; Jaffrey, S.R. Comprehensive analysis of mRNA methylation reveals enrichment in 3' UTRs and near stop codons. Cell 2012, 149, 1635-1646. [CrossRef] [PubMed]

112. Cui, X.; Meng, J.; Rao, M.K.; Chen, Y.; Huang, Y. HEPeak: An HMM-based exome peak-finding package for RNA epigenome sequencing data. Bmc Genom. 2015, 16 (Suppl. S4), S2. [CrossRef]

113. Liu, N.; Parisien, M.; Dai, Q.; Zheng, G.; He, C.; Pan, T. Probing N6-methyladenosine RNA modification status at single nucleotide resolution in mRNA and long noncoding RNA. RNA 2013, 19, 1848-1856. [CrossRef] [PubMed]

114. Liu, N.; Dai, Q.; Zheng, G.; He, C.; Parisien, M.; Pan, T. N(6)-methyladenosine-dependent RNA structural switches regulate RNA-protein interactions. Nature 2015, 518, 560-564. [CrossRef] [PubMed]

115. Dhir, A.; Dhir, S.; Proudfoot, N.J.; Jopling, C.L. Microprocessor mediates transcriptional termination of long noncoding RNA transcripts hosting microRNAs. Nat. Struct. Mol. Biol. 2015, 22, 319-327. [CrossRef] [PubMed]

116. Alarcon, C.R.; Lee, H.; Goodarzi, H.; Halberg, N.; Tavazoie, S.F. N6-methyladenosine marks primary microRNAs for processing. Nature 2015, 519, 482-485. [CrossRef]

117. Peng, Z.; Cheng, Y.; Tan, B.C.; Kang, L.; Tian, Z.; Zhu, Y.; Zhang, W.; Liang, Y.; Hu, X.; Tan, X.; et al. Comprehensive analysis of RNA-Seq data reveals extensive RNA editing in a human transcriptome. Nat. Biotechnol. 2012, 30, 253-260. [CrossRef]

118. Ramaswami, G.; Zhang, R.; Piskol, R.; Keegan, L.P.; Deng, P.; O'Connell, M.A.; Li, J.B. Identifying RNA editing sites using RNA sequencing data alone. Nat. Methods 2013, 10, 128-132. [CrossRef]

119. Sakurai, M.; Ueda,H.; Yano, T.; Okada, S.; Terajima, H.; Mitsuyama, T.; Toyoda, A.; Fujiyama, A.; Kawabata,H.; Suzuki, T. A biochemical landscape of A-to-I RNA editing in the human brain transcriptome. Genome Res. 2014, 24, 522-534. [CrossRef]

120. Salameh, A.; Lee, A.K.; Cardo-Vila, M.; Nunes, D.N.; Efstathiou, E.; Staquicini, F.I.; Dobroff, A.S.; Marchio, S.; Navone, N.M.; Hosoya, H.; et al. PRUNE2 is a human prostate cancer suppressor regulated by the intronic long noncoding RNA PCA3. Proc. Natl. Acad. Sci. USA 2015, 112, 8403-8408. [CrossRef]

121. Klionsky, D.J.; Emr, S.D. Autophagy as a regulated pathway of cellular degradation. Science 2000, 290, $1717-1721$. [CrossRef] [PubMed]

122. Feng, Y.; He, D.; Yao, Z.; Klionsky, D.J. The machinery of macroautophagy. Cell Res. 2014, $24,24-41$. [CrossRef] [PubMed]

123. Chen, P.; Cescon, M.; Bonaldo, P. Autophagy-mediated regulation of macrophages and its applications for cancer. Autophagy 2014, 10, 192-200. [CrossRef] [PubMed] 
124. Zhang, S.F.; Wang, X.Y.; Fu, Z.Q.; Peng, Q.H.; Zhang, J.Y.; Ye, F.; Fu, Y.F.; Zhou, C.Y.; Lu, W.G.; Cheng, X.D.; et al. TXNDC17 promotes paclitaxel resistance via inducing autophagy in ovarian cancer. Autophagy 2015, 11, 225-238. [CrossRef]

125. YiRen, H.; YingCong, Y.; Sunwu, Y.; Keqin, L.; Xiaochun, T.; Senrui, C.; Ende, C.; XiZhou, L.; Yanfan, C. Long noncoding RNA MALAT1 regulates autophagy associated chemoresistance via miR-23b-3p sequestration in gastric cancer. Mol. Cancer 2017, 16, 174. [CrossRef]

126. Huang, F.; Chen, W.; Peng, J.; Li, Y.; Zhuang, Y.; Zhu, Z.; Shao, C.; Yang, W.; Yao, H.; Zhang, S. LncRNA PVT1 triggers Cyto-protective autophagy and promotes pancreatic ductal adenocarcinoma development via the miR-20a-5p/ULK1 Axis. Mol. Cancer 2018, 17, 98. [CrossRef]

127. Xiu, Y.L.; Sun, K.X.; Chen, X.; Chen, S.; Zhao, Y.; Guo, Q.G.; Zong, Z.H. Upregulation of the lncRNA Meg3 induces autophagy to inhibit tumorigenesis and progression of epithelial ovarian carcinoma by regulating activity of ATG3. Oncotarget 2017, 8, 31714-31725. [CrossRef]

128. Xiong, H.; Ni, Z.; He, J.; Jiang, S.; Li, X.; He, J.; Gong, W.; Zheng, L.; Chen, S.; Li, B.; et al. LncRNA HULC triggers autophagy via stabilizing Sirt1 and attenuates the chemosensitivity of HCC cells. Oncogene 2017, 36, 3528-3540. [CrossRef]

129. Zhang, H.; Zhang, N.; Liu, Y.; Su, P.; Liang, Y.; Li, Y.; Wang, X.; Chen, T.; Song, X.; Sang, Y.; et al. Epigenetic regulation of NAMPT by NAMPT-AS drives metastatic progression in triple-negative breast cancer. Cancer Res. 2019, 79, 3347-3359. [CrossRef]

130. Liu, C.; Fu, H.; Liu, X.; Lei, Q.; Zhang, Y.; She, X.; Liu, Q.; Liu, Q.; Sun, Y.; Li, G.; et al. LINC00470 coordinates the epigenetic regulation of ELFN2 to distract GBM cell autophagy. Mol. Ther. J. Am. Soc. Gene Ther. 2018, 26, 2267-2281. [CrossRef]

131. Li, L.; Chen, H.; Gao, Y.; Wang, Y.W.; Zhang, G.Q.; Pan, S.H.; Ji, L.; Kong, R.; Wang, G.; Jia, Y.H.; et al. Long Noncoding RNA MALAT1 promotes aggressive pancreatic cancer proliferation and metastasis via the stimulation of autophagy. Mol. Cancer Ther. 2016, 15, 2232-2243. [CrossRef]

132. Xu, S.; Wang, P.; Zhang, J.; Wu, H.; Sui, S.; Zhang, J.; Wang, Q.; Qiao, K.; Yang, W.; Xu, H.; et al. Ai-lncRNA EGOT enhancing autophagy sensitizes paclitaxel cytotoxicity via upregulation of ITPR1 expression by RNA-RNA and RNA-protein interactions in human cancer. Mol. Cancer 2019, 18, 89. [CrossRef] [PubMed]

133. Bester, A.C.; Lee, J.D.; Chavez, A.; Lee, Y.R.; Nachmani, D.; Vora, S.; Victor, J.; Sauvageau, M.; Monteleone, E.; Rinn, J.L.; et al. An integrated genome-wide CRISPRa approach to functionalize lncRNAs in drug resistance. Cell 2018, 173, 649-664 e620. [CrossRef] [PubMed] 